\title{
How Large are Earnings Penalties for Self- Employed and Informal Wage Workers?
}

\author{
T. H. Gindling ${ }^{1}$, Nadwa Mossaad ${ }^{1}$ and David Newhouse ${ }^{2^{*}}$
}

\author{
* Correspondence: \\ dnewhouse@worldbank.org \\ ${ }^{2}$ Poverty and Equity Global Practice, \\ World Bank, Washington, DC, USA \\ Full list of author information is \\ available at the end of the article
}

\begin{abstract}
This paper examines the earnings penalties and premiums associated with different types of employment in 73 countries. Workers are divided into four categories: non-professional own-account workers, employers and own-account professionals, informal wage employees, and formal wage employees. Approximately half of the workers in low income countries are non-professional own-account workers, and the majority of the rest are informal employees. Fewer than 10 percent are formal employees, and only 2 percent of workers in low income countries are employers or own-account professionals. As per capita gross domestic product increases across countries, there are large net shifts from non-professional own-account work into formal wage employment. Across all regions and income levels, non-professional own-account workers and informal wage employees face an earnings penalty compared with formal wage employees. But in low income countries, this earnings penalty is small, and non-professional own-account workers earn a positive premium relative to all wage employees. Earnings penalties for non-professional own-account workers tend to increase with gross domestic product and are largest for female workers in high income countries. On average, employers and own-account professionals earn a premium compared to employees, although there are important differences across countries and between men and women. In terms of regional differences, earnings premiums for employers and professionals are largest for men in middle income Latin American countries. On the other hand, women employers and professionals do not earn a statistically significant premium compared to employees in any region of the world. These results are consistent with compensating wage differentials and firm quasi-rents playing important roles in explaining cross-country variation in earnings penalties, and raise questions about the extent to which the unskilled self-employed are rationed out of formal wage work in low income countries.
\end{abstract}

JEL Codes: J31, 017

\section{Introduction}

A defining characteristic of labor markets in developing countries is the high proportion of workers who are self-employed or work in the informal sector. Despite a sizeable literature, there remains little consensus on the extent to which self-employed and informal sector workers are in those sectors because they are excluded from formal sector employment or because they choose to be in those sectors based on pecuniary or non-pecuniary factors. Earnings penalties for self- and informal employment are

(c) The Author(s). 2016 Open Access This article is distributed under the terms of the Creative Commons Attribution 4.0 International License (http://creativecommons.org/licenses/by/4.0/), which permits unrestricted use, distribution, and reproduction in any medium, provided you give appropriate credit to the original author(s) and the source, provide a link to the Creative Commons license, and indicate if changes were made. 
often interpreted as evidence of exclusion from higher-paid formal employment. Many studies have examined earnings differences between informal and formal employment, and self- and wage employment, for individual countries or for some regions of the world such as Latin America. However, comparative literature on how and why these earnings gaps differ across countries around the world is sparse.

This paper contributes to the ongoing discussion on self-employment, informality, labor market segmentation and earnings differentials. It uses multiple years of data from the World Bank International Income Distribution Database (I2D2), a comprehensive set of harmonized household surveys, to estimate the proportion and wage differentials of self-employed and wage employees from 73 countries around the world. The first contribution is to provide new comprehensive estimates of the proportion of workers who are non-professional own-account workers (interpreted broadly as a measure of unskilled self-employment), employers and own-account professionals (a measure of skilled self-employment), informal sector employees and formal sector employees. Our second major contribution is an estimate of the wage penalties or premiums for each of these groups in countries around the world. The estimated premiums/penalties for each country/year are from ordinary least squares estimates of wage equations and control for worker characteristics such as age, education, gender, as well as industry of work.

This study addresses the following questions: What proportion of workers fall into the following categories: non-professional own-account workers, employers and ownaccount professionals (which, for conciseness, we will also refer to as "employers and professionals"), informal employees and formal employees? How does the proportion of workers in each category change as per capita GDP increases? How does the proportion of workers in each category differ across countries and regions? Do workers earn an earnings premium or pay an earnings penalty for self-employment and informal employment? Is there a difference between the self-employed who are employers and own-account professionals and those who are non-professional own-account workers? How do the estimated self-employment and informal employee earnings penalties or premiums change as per capita GDP increases? How do estimates of these premiums or penalties vary across countries and regions? Finally, how do these penalties or premiums differ between types of workers within countries?

We find that approximately half of the workers in low income countries are nonprofessional own-account workers. Fewer than 10 percent are formal employees, and only 2 percent of workers in low income countries are employers or professionals. As per capita GDP increases, the proportion of workers who are formal employees, employers, and professional own-account workers increases, while the proportion of workers who are non-professional own-account workers falls.

Across all regions and income levels, non-professional own-account workers and informal sector workers face an earnings penalty compared to formal employees. However, both the non-professional own-account and informal earnings penalties are small (and often insignificant) in low income countries. Furthermore, in a larger sample of 20 low income countries, self-employed workers earn a statistically significant wage premium compared to the average (informal and formal) wage employee. The earnings penalties faced by non-professional own-account and informal employees tend to increase as a country's GDP increases. The earnings penalties for informal employees are 
largest in middle income countries, while the earnings penalties for non-professional own-account workers are largest in high income countries.

On average, across all countries in the sample, employers and own-account professional workers earn a premium compared to employees, although there are important differences across countries and between men and women. Gender differences are particularly strong when examining earnings premiums for employers and professionals. Overall, male employers and professionals earn an 18 percent premium compared with all employees, while women face a penalty of roughly the same magnitude. In terms of regional differences, earnings premiums for employers and professionals are largest for men in middle income Latin American countries. On the other hand, women employers and professionals do not earn a statistically significant premium compared to employees in any region of the world. In addition, neither male nor female employers and professionals earn premiums in either high income or developing countries in Europe and Central Asia. Conditions appear to be favorable for employers and professionals in Latin America, as they are more numerous and earn greater premiums versus formal employees. In contrast, conditions seem to be less favorable for the same group in Europe and Central Asia, where they are fewer and do not earn premiums vs. formal employees.

The rest of the paper is organized as follows. Section II summarizes the theoretical literature on wage differentials and labor market segmentation as well as the latest empirical findings across countries. Section III briefly describes the data, while section IV describes the methodology used to estimate wage differentials for self-employed and informal workers across various groups. In section $\mathrm{V}$ we present estimates of the proportion of self-employed, informal, formal, and salaried workers from around the world. In section VI, the main section of the paper, we examine the wage differentials for selfemployed, informal, formal, and salaried workers by country income level and regions of the world. In particular, we empirically test the hypothesis that the informal and selfemployment sectors are heterogeneous by dividing self-employment into professional and non-professional, by dividing employees into formal and informal, and by further examining the wages of these group across education level, experience (measured by age), gender, and whether there are urban/rural differences. Section VII concludes.

\section{Literature Review}

\subsection{Theoretical}

In a standard neo-classical model in which labor markets are perfectly competitive, labor is free to move between sectors and workers maximize earnings, identical workers would earn the same amount whether they are self-employed, employees in small firms, or employees in large firms. In a competitive labor market, this will be true even though larger firms may offer facilities that boost worker productivity, such as access to capital, export markets, and the opportunity to specialize. Assuming diminishing marginal returns to labor in wage employment, the free movement of labor will equalize earnings between wage employees in different firms and the self-employed.

What are departures from the competitive labor market model that could lead to an observed earnings penalty or premium for self-employed workers vs. employees, or for employees in different types of firms? Most explanations of persistent earnings differentials between the self-employed and employees are based on barriers to movement in 
response to a systematic earnings difference between sectors. A traditional view of labor markets in developing economies is that they are segmented or dualistic, where formal sector jobs are restricted by minimum wage, tax laws, and labor market regulations that limit employment in the formal sector. Key to this view is that either government regulations, especially those on labor market, or efficiency wages limit the availability of formal sector employment and make it difficult for non-formal sector workers to compete for formal sector jobs. That is, some workers are "excluded" from the formal sector by labor market regulations or efficiency wages. This view argues that workers unable to find adequate employment opportunities in the formal sector are forced to take employment as self-employed workers or employees in the low paid, marginal informal sector firms. In this view, both self-employed workers and informal employees are "excluded" from the formal sector. Limiting competition from these "excluded" workers keeps the wages of formal sector workers above the market-clearing wage, resulting in wage penalties for the excluded workers. The dualistic labor market view subscribes to the notion that informality stems from an imbalance between high population growth and the slow growth of "good" formal jobs (Harris and Todaro 1970; Fields 2005, 2009; Tokman 1978; De Mel et al. 2010).

One distinguishing feature of labor market segmentation is earnings differentials; earnings gaps between informal sector workers (both self-employed and employees) and equally-qualified formal wage and salaried employees has often been interpreted as a measure of the degree of labor market segmentation (Lewis 1954; Mincer 1962; Fields 2009). In this view, self-employment and informal wage employment are prevalent in low income economies because the formal economy is incapable of providing enough good, high-wage jobs. As countries develop, the proportion of workers who are self-employed and informal employees should fall, and the wage differential between the self-employed and informal employees vs. formal employees should eventually disappear.

An alternative explanation for why there might be a self-employment or informal employee earnings penalty that does not rely on segmented labor markets is that workers maximize utility rather than earnings, leading to systematic compensating wage differentials. For example, if self-employment is more desirable than wage employment for reasons unrelated to earnings, such as greater autonomy and flexibility, we would expect to see a self-employment earnings penalty. Unlike the labor market segmentation explanation for self-employment and informal sector earnings penalties, the compensating differential explanation suggests that the earnings penalty will be particularly large in more developed countries and among better educated workers, where the opportunity cost of time is higher and therefore the flexibility of self-employment will be valued more.

A third possibility is that the standard neo-classical labor market model is correct, but that empirically the compensation of self-employed workers, informal employees, or formal employees is not measured properly. Absolute estimates of wage gaps are inherently imprecise due to the difficulty of measuring self-reported profits and of valuing non-wage benefits. For example, self-employed workers might systematically under-report earnings, which could lead to an observed self-employed penalty even when none exists (Hurst et al. 2010). On the other hand, the self-reported earnings of employees include only returns to labor, while the self-reported earnings of the self-employed may also include returns to capital, as well as returns to the risk of entrepreneurship. Failing to account for this may overestimate the self-employment earnings premium. Furthermore, formal 
sector wage employees often do not include in their reported earnings the value of nonwage benefits such as firms' contributions to pensions, sick pay, severance pay, and health care, while self-employed workers and informal sector workers, who do not receive these non-wage benefits, may receive higher paid wages as compensating differentials. In the competitive labor market described above, self-employed and informal sector employees would include compensation for these foregone non-wage benefits (Meghir et al. 2015), which would lead to overestimation of self-employment and informal sector earnings (and may even lead to a measured premium for self-employment and informality).

When examining earnings premiums, it is useful to distinguish between low-skilled self-employment, entrepreneurial self-employment, and informal wage employment. While many have identified self-employment in developing countries with the informal sector, others identify self-employment with entrepreneurship (Bennett and Estrin 2010; de Soto 1989). Higher skilled, more entrepreneurial self-employed may earn a wage premium compared to formal employment. This could arise if the most motivated and productive workers became entrepreneurs, or if there are compensating earnings differentials for entrepreneurs that compensate for increased risk and volatility, or if wage employees' compensation is underestimated in the data.

High adjustment or entry costs into entrepreneurship could also contribute to an observed self-employment premium because the future earnings of entrepreneurs would need to compensate for these costs. One such adjustment cost is the initial investment needed to set up a small business, often financed through credit. If credit markets are imperfect and it is difficult to obtain credit, then self-employed entrepreneurs must be paid more than they could get as employees in order to compensate them for the high costs of credit. On the other hand, in low income countries many self-employment opportunities may require little capital, while searching for higher-paid wage employment may involve relocating or other expensive search costs. ${ }^{1}$ For those facing credit constraints, starting a low-level business as a petty trader or farmer may entail less upfront cost than searching for a wage job. In this case, imperfect credit markets would create a self-employment earnings penalty.

Another adjustment cost of self-employment and entrepreneurship could be associated with complying with regulations and permits needed to start a business. These costs can be substantial in many developing countries (de Soto 1989). If there are regulatory and other costs to becoming self-employed that limit access, then self-employed workers will be paid more to compensate for these additional costs, causing an observed self-employment wage premium. For example, if it is costly and time consuming to obtain all of the necessary permits and permissions to work as self-employed (i.e., a more regulated economy), or if taxes are higher for the self-employed than for employees, then self-employed workers may be paid more than they could get as employees as compensation for the high costs of entry. Note that the self-employed would need to be compensated for these regulatory costs even if they attempt to avoid them because there may be costs to violating these regulations.

A final possible reason why formal sector wage employees may earn more than similar self-employed workers is that formal sector employees may successfully bargain for a portion of the quasi-rents earned by firms. Several studies have identified noncompetitive rents as an important determinant of inter-industry wage differentials. ${ }^{2}$ Most recently, Abowd et al. (2012) find that shared quasi-rents account for a large 
percentage of inter-industry wage differentials in the United States and France. Based on wage bargaining models that allow for on the job search (i.e. Cahuc et al. (2006)), they posit that the wage formal sector firms pay employees is the sum of the opportunity cost of wage employment plus the workers' share of quasi-rents. Under the assumption that earnings in selfemployment or the informal sector is an approximation of comparable formal sector wage workers' opportunity cost, the self-employment and informal employment earnings penalties will be determined by the bargaining power of workers and the size of the quasi-rents. That is, the self-employment and informal sector earnings penalty will increase if the relative bargaining power of formal sector employees increases or if firms' quasi-rents increase.

The bargaining power of formal sector employees, and therefore self-employment and informal sector wage penalties, could be increased by the presence of efficiency wages or labor market institutions such as unions. Van Reenen (1996) focuses on the role of innovation and increased labor productivity in generating quasi-rents, which firms can then "share" with workers as efficiency wages. That study presents strong evidence that workers in British firms that adopt more innovative and productive technologies earn more than identical workers in other firms. It argues that more productive firms allocate part of their "quasi-rents" from innovation to workers in the form of higher wages. To the extent formal sector firms share quasi-rents with workers, this would contribute to a self-employment and informal sector wage penalty. These penalties would be larger in countries where firms are more productive, and therefore have more quasi-rents to share, and/or in countries in which labor market institutions favor workers in the wage bargaining process.

In one traditional dualistic model of economic development, the formal sector in least developed countries is small (and self-employment and informal employment are large) because lack of demand, credit, reliable inputs, and export markets keep scale and productivity low for formal sector products (see Lewis 1954 and La Porta and Schleifer 2014). For this reason, formal sector firms in low income countries will be less productive. Since firms in low income countries tend to be less productive than those in more developed countries, quasi-rents and by extension self-employment penalties would likely be smaller for workers in low income countries. As demand increases for domestic products and credit, input and export markets expand, the scale of production and productivity increase in the formal sector. As countries develop, firms not only earn more quasi-rents, but labor market institutions may also become more effective in increasing workers' bargaining power. Both of these factors will lead to increased earnings for formal sector employees relative to the self-employed and informal sector workers.

\subsection{Empirical}

This paper contributes to the literature on the estimation of the magnitudes of earnings differentials between self-employed and informal sector employees relative to formal sector employees in developing economies. Many of these studies are based on data from Latin America and the Caribbean and most focus on middle income countries. Almost universally, these studies find that workers in the informal sector earn less than equally qualified employees in the formal sector (i.e. Heckman and Hotz 1986; Gindling 1991; Basch and Paredes-Molina 1996; Launov 2006; and Günther and Launov 2012). However, not all informal sector workers are self-employed, and the self-employed may 
be very different from informal sector employees. In a review of the evidence from Latin America, Perry et al. (2007, p.6) conclude that the self-employed voluntarily opt out of the formal sector, while informal salaried workers are queuing for more desirable jobs in either the formal salaried sector or as self-employed workers.

When researchers estimate formal-informal wage differentials separately for informal sector employees and self-employed workers, they typically find different results for the two groups. Compared to formal sector wage and salary employees, Arias and Khamis (2009) find an earnings penalty for informal wage and salary employees but an earnings premium for self-employed workers in Argentina. Nguyen et al. (2013) find the same result in Vietnam. Using quantile regressions, Nguyen et al. (2013) further find that both informal employees and the self-employed are likely to face an earnings penalty at the bottom of the earnings distribution and an earnings premium at the top. In Peru, Saavedra and Chong (1999) find an earnings penalty for informal sector employees, but no difference between the wages of informal self-employed workers and formal sector employees. Maloney (1999) finds that workers who transition from wage and salary employment into self-employment in Mexico benefit from higher earnings, while workers who transition into informal sector wage and salary employment experience a decline in earnings.

The studies reviewed thus far are from developing economies. Asteibro and Chen (2014) review estimates from OECD and other developed economies. They conclude that "these studies confirm that the estimated average returns to self-employment are negative, or at least not positive" in high income countries (p. 89). Asteibro and Chen (2014) show that, at least for the United States, the self-employment penalty may exist because entrepreneurs systematically underrepresent their earnings. Most studies indicate that the distribution of earnings among the self-employed (entrepreneurs) is more skewed than that of employees, with a somewhat thicker and longer tail at the upper end of earnings. This suggests that there may be a self-employment wage penalty at the bottom of the distribution but a premium at the top. Sorgner et al. (2014) show that this is true in Germany. This study further distinguishes the self-employed in Germany between those who have employees and those without employees, and find that, on average, there is a wage premium for those with employees and a wage penalty for those without.

We know of very few studies that use comparable data and techniques to compare informal or self-employment earnings differentials across a large set of countries from different regions of the world and for a wide range of income groups. Gasparini and Tornarolli (2007) present estimates for 19 Latin American countries and conclude that formal salaried workers earn substantially more than informal salaried workers but that there are no statistically significant differences in wages between self-employed and salaried workers. The only study that we know of to compare estimates from countries in different regions of the world is Bargain and Kwenda (2011), who compare estimates from two Latin American countries (Brazil and Mexico) and South Africa. They find an average wage penalty for informal employees in all three countries. However, using quantile regressions (and controlling for individual fixed effects), they show that the informal sector wage penalty is larger in the lower part of the conditional distribution and tends to disappear at the top. For self-employed workers, the premiums differ by country. In Mexico, there is a wage premium for self-employment, especially at the top of the distribution; in Brazil, there is no significant difference in earnings between the self-employed and employees; while in South Africa, both informal sector and self- 
employed workers pay an earnings penalty at most points in the distribution, relative to formal sector employees.

In summary, while the literature on wage differentials points to consistent earnings penalties for wage and salary employment in the informal sector relative to the formal sector, this is not the case for self-employment relative to wage and salaried employment in either sector. Most published studies conclude that self-employed workers do not earn less than equally qualified formal sector wage and salaried employees. However, most of these studies are from middle income and/or Latin American countries; there are few studies of self-employment earnings differentials in low income countries outside of Latin America. Our paper contributes to the literature on informal and self-employment wage penalties or premiums by estimating and comparing these earnings differentials for a wider range of developing and high income countries than currently exists in the literature.

\section{Data}

The data source for this paper is the International Income Distribution Database (I2D2), ${ }^{3}$ a database of micro-level household surveys harmonized by the Development Economics Research Group of the World Bank, This database consists of nationally representative labor force surveys, budget surveys, or living standards measurement surveys. In many cases, the surveys provide information on the earnings and other relevant socioeconomic characteristics of self-employed and wage and salary employees. The data include three sets of consistently defined and coded variables: (i) demographic, (ii) education, and (iii) labor force variables.

Not all variables are available in all countries and years. We limit our analysis to surveys where we can identify whether the worker is self-employed or a wage and salary employee, and where data is collected on the earnings of both the self-employed and wage and salaried workers. ${ }^{4}$ In most countries, data are available for multiple years. Our full sample consists of 347 surveys (country/year combinations), representing 73 countries, from 1980 to 2013. We limit our analysis to the working age population, 1565 years old. The full country-year combinations available for our analysis, as well as the estimated earnings premiums(+)/penalties(-) for each country/year observation, are listed in the Additional file 1.

We begin by examining the earnings differentials between self-employed workers and all wage and salaried employees. We are able to examine earnings differentials using 347 household surveys from 73 countries. Two thirds of these surveys (62 percent) are from Latin America, while 90 percent are from either Latin America or Europe and Central Asia.

We recognize that within the self-employed there may be large differences between employers and professional own-account workers (i.e. lawyers, doctors, accountants, etc.) and non-professional own-account workers (unskilled self-employed). Therefore, where possible, we separate self-employed workers into two categories: (i) nonprofessional own-account workers and (ii) employers and own-account professionals. We are able to examine earnings differentials between these two types of self-employed workers vs. employees in 152 surveys and 42 countries. Over 50 percent of these surveys are from Europe and Central Asia (33 percent from high income ECA countries, 18 percent from developing ECA countries) and 34 percent are from Latin America.

There may also be substantial differences between formal and informal employees, especially in developing countries. We identify formal employees as those who exhibit 
one or more of the following characteristics: union membership, a formal work contract, or an employer who pays towards social security or health insurance. Employees who are not identified as formal are classified as informal. We are able to examine differences between formal and informal employees and between self-employed workers vs. informal or formal employees in 190 surveys from 34 countries. Most (90 percent) of the surveys where we can identify formal from informal employees are from by Latin America.

\section{Methodology: Estimating the Self-Employment Earnings Penalty/Premium}

We estimate the earnings premiums/penalties in each survey using individual worker-level (i) data to estimate the following earnings equation for each country(c)/year(t) combination:

$$
\operatorname{Ln} Y_{i c t}=\alpha+E P_{c t} * S E_{i c t}+\beta_{c t} X_{i c t}+\mu_{i c t}
$$

Where

- $\mathrm{Y}_{\mathrm{ict}}$ is the dependent variable, self-reported monthly earnings of worker i in country $\mathrm{c}$ in year $\mathrm{t}$.

- $\mathrm{X}_{\text {ict }}$ is a set of variables that partially control for observed differences between workers and industries. These are: years of education, years of education squared, age, age squared, a gender dummy variable, an urban/rural dummy variable, a set of dummy variables for one-digit industry code, and a set of dummy variables representing the frequency of wage payments. ${ }^{5}$

- $\mu_{i c t}$ is the error term

- $S E_{i c t}$ is a dummy variable indicating whether the worker is self-employed (1) or a wage and salary worker (0)

- $\mathrm{EP}_{\mathrm{ct}}$ is the average self-employment earnings premium, estimated separately for each survey (country(c)/year(t) combination). Specifically, $E P_{c t}$ is the percent by which the earnings of the self-employed differ from the earnings of wage and salary workers. If $\mathrm{EP}_{\mathrm{ct}}$ is positive, that indicates that there is an earnings premium for selfemployment; a negative $E P_{c t}$ indicates an earnings penalty.

The first set of earnings differential estimates that we present use this specification to estimate the earnings premium/penalty between self-employed workers and all employees. In a second set of estimates we re-estimate equation 1 and include two self-employment dummy variables to identify non-professional own-account workers and employers and own-account professionals (the reference category is all employees). From this regression we obtain estimates of the earnings differentials between non-professional own-account workers vs. employees, employers and professionals vs. employees, and non-professional own-account workers vs. employers and professionals. In a third set of estimates we separate formal and informal sector employees and estimate the earnings differentials between them, as well as between all self-employed workers vs. informal employees, and all self-employed workers vs. formal employees. Finally, we re-estimate equation 1 and interact the two self-employed and formal/informal dummy variables to obtain estimates of the earnings differentials between non-professional own-account workers vs. formal sector workers, non-professional own-account workers vs. informal employees, and employers and professionals vs. non-professional own-account workers. 
Tables 3 and 4 summarize the results of these estimations for all countries in our sample by income level and regions. In calculating these means across surveys we weight the estimates in three ways. First, in calculating means across countries; the estimates of the earnings differentials in each country are weighted by total employment for that country and year in order to take into account the differences in the employment level for each country. In addition, because the number of surveys in the data for each country are different, the results from each survey (country/year combination) are also weighted by the inverse of the number of surveys for each country. Weighted this way, each country is effectively counted once even if there are more than one survey for that country. Finally, because the estimates of earnings differentials in each country are based on varying sample sizes and thus have different standard errors, we also weight the results from each survey by the inverse of the estimated standard error of the average self-employment earnings premium, which we estimate separately for each survey (i.e. country/year combination- $\left.E P_{c t}\right)$. This accounts for heteroscedasticity when aggregating estimated selfemployment premiums across surveys.

\section{The Extent of Self-Employment and Informal Employment Around the World}

Table 1 presents the mean proportion of workers in each employment category across all surveys in the sample and for countries at different income levels. Specifically, Table 1 presents the proportion of workers who are: self-employed (divided between non-professional own-account vs. employers and own-account professionals) and employees (divided between informal employees and formal employees). Approximately 50 percent of workers in low income countries are nonprofessional own-account workers (Table 1b). As per capita income increases, the proportion of non-professional own-account workers falls to 20 percent in upper middle income countries and 7 percent in high income countries. At the same time, as per capita income increases from low to upper-middle income countries the proportion of employers and professionals increases from 2 percent in low income countries to over 4.5 percent in upper middle income and high income countries.

Fewer than half of workers in low income countries are wage and salaried employees (see Table 1a). This proportion increases as the per capita income of a country grows, and almost 90 percent of workers in high income countries are wage and salaried employees. In addition, the proportion of employees in the formal sector increases, from less than 10 percent of workers in low income countries to almost half of all workers in upper middle income countries (Table 1c). We do not have direct estimates of informal and formal sector employees for high income countries, but we expect that most wage employees are formal in high income OECD countries. ${ }^{6}$

Table 2 presents the proportion of workers in each category by region of the world. For most regions, the proportion of workers in each category follows the existing patterns by income group. For example, in regions characterized by low and lower-middle income countries (East Asia and the Pacific, Middle East and North Africa (MENA), South Asia and Sub-Saharan Africa) ${ }^{7}$ the proportion of formal sector employees is 


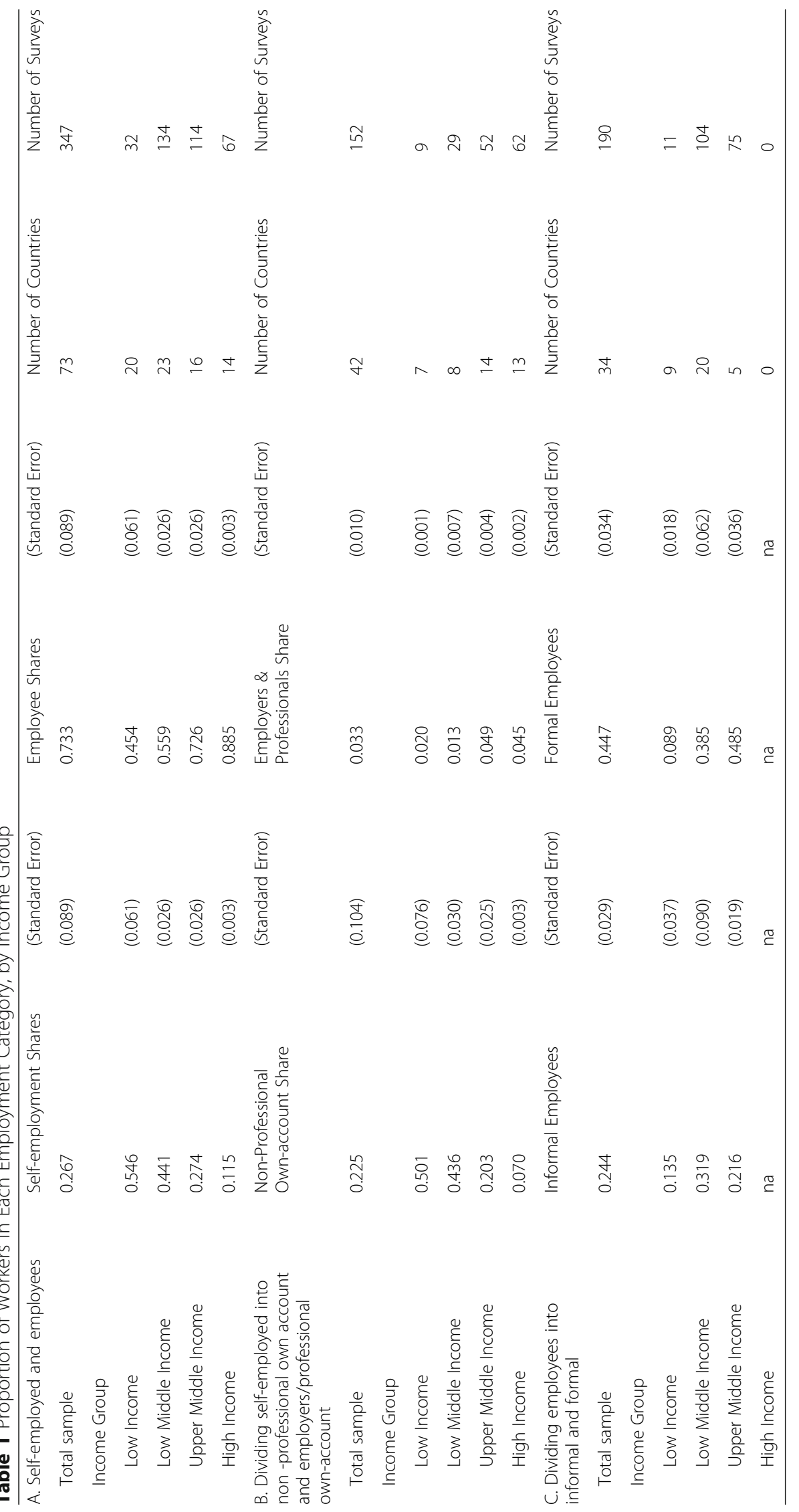




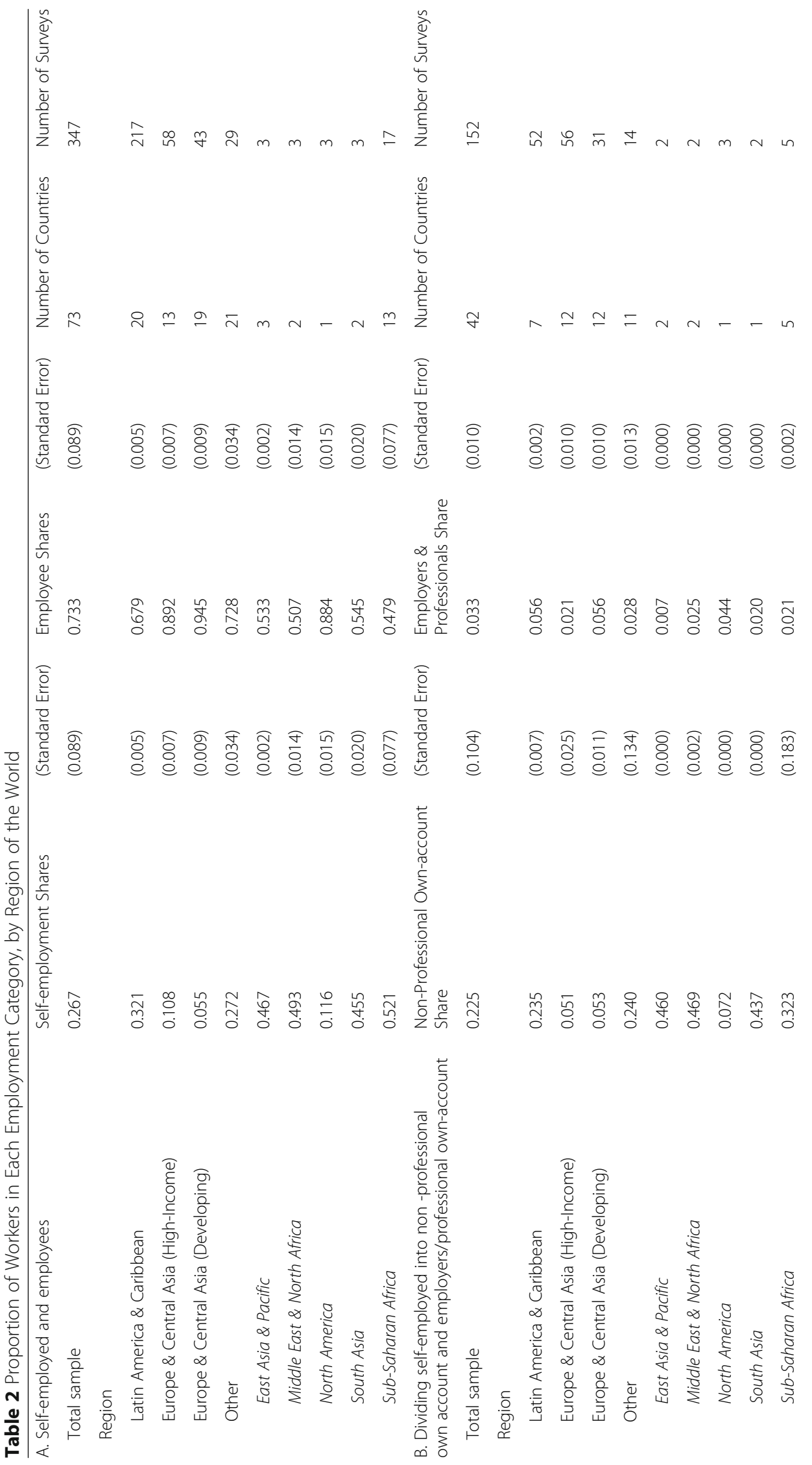




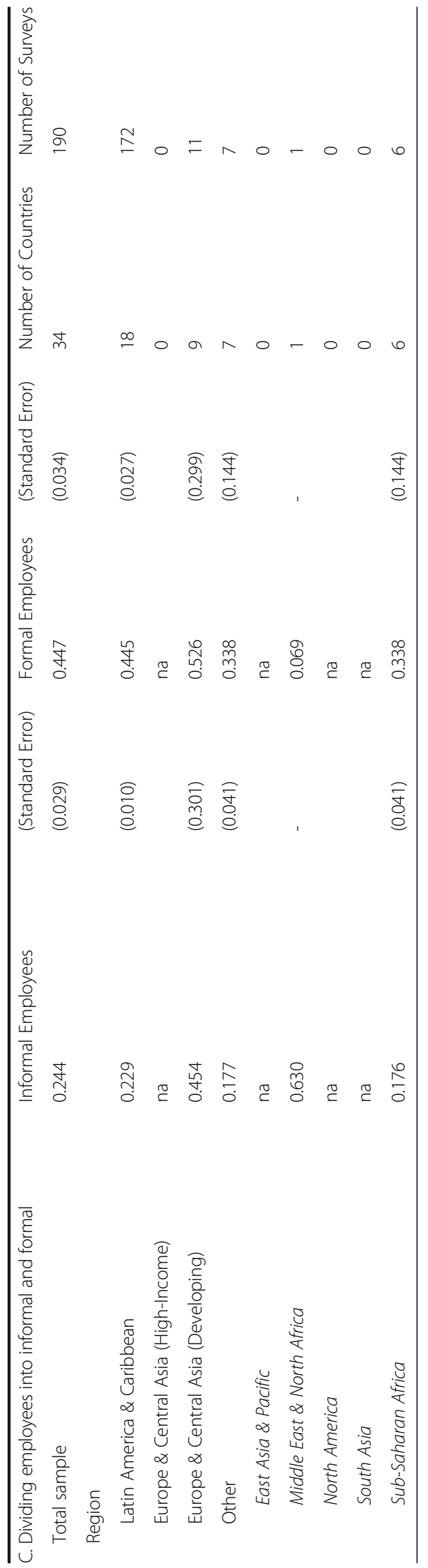


relatively small and the proportion of non-professional own-account worker is relatively large (Table $2 b$ and $c$ ). At the other end of the income scale, in high income countries of Europe and North America, the proportion of formal sector employees is relatively large and the proportion of non-professional own-account worker is relatively small. In Latin America, composed mostly of middle income countries, the proportion of workers in each category is between those of the low income and high income countries.

Middle income countries in Europe and Central Asia combine elements of high income European and Central Asian economies with those of middle income Latin American countries. For example, the proportion of self-employed workers in developing European and Central Asian countries is very low, 5 percent, compared to 11 percent in high income Europe and Central Asia and 32 percent in middle income Latin America. On the other hand, the proportion of informal employees in developing European and Central Asian countries is similar to the 23 percent in Latin America. Within the developing European and Central Asian economies we can identify informal vs. formal employees only for the Balkan and Central Asian economies. In these Balkan and Central Asia economies the proportion of informal employees in the developing economies of Europe and Central Asia is high at 45 percent. While using the surveys that we have available we cannot identify informal vs. formal employment in the transition economies of Eastern Europe, other studies of informal employment in the transition economies report levels of less than 45 percent. For example, Lehmann (2015) estimates the size of informal employment in Russia at between 6 percent and 19 percent of workers (depending on the definition of "informal").

\section{Earnings Penalties and Premiums for Self-Employment and Informal Em- ployees around the World}

In Table 3 we report the results of the estimation of wage penalties (-) and premiums $(+)$ for all self-employed workers vs. all employees, non-professional own-account workers vs. formal and informal employees, employers and professionals vs. formal and informal employees, and informal vs. formal employees.

On average across countries a clear ordering emerges; after controlling for education, age, gender, region of residence and industry sector, employers and own-account professionals earn the most. In particular, employers and professionals earn more than formal and informal employees, and more than self-employed non-professional ownaccount workers. After employers and professionals come formal sector employees, who earn more than non-professional own-account workers and informal employees. Finally, non-professional own-account workers earn more than the lowest-paid category, informal employees.

\subsection{By Level of Development (GDP per Capita)}

Table 3 also presents earnings differentials separately for countries by income level. The estimates show substantial differences between low, middle and high income countries. Informal employees face an earnings penalty compared to formal employees in each income group. The informal earnings penalty is small and not significantly different from zero in low income countries. The informal employees' earnings penalty 


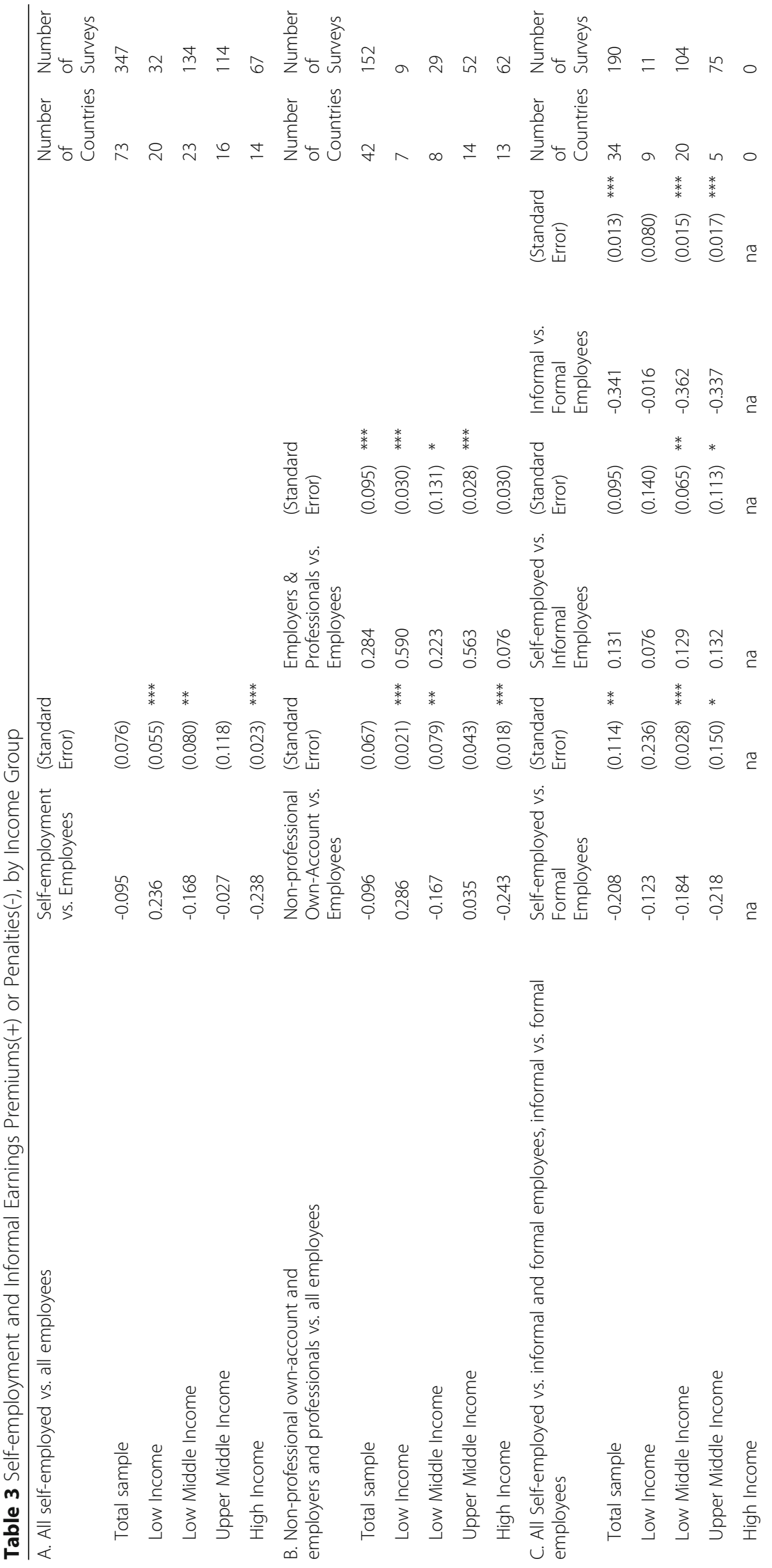




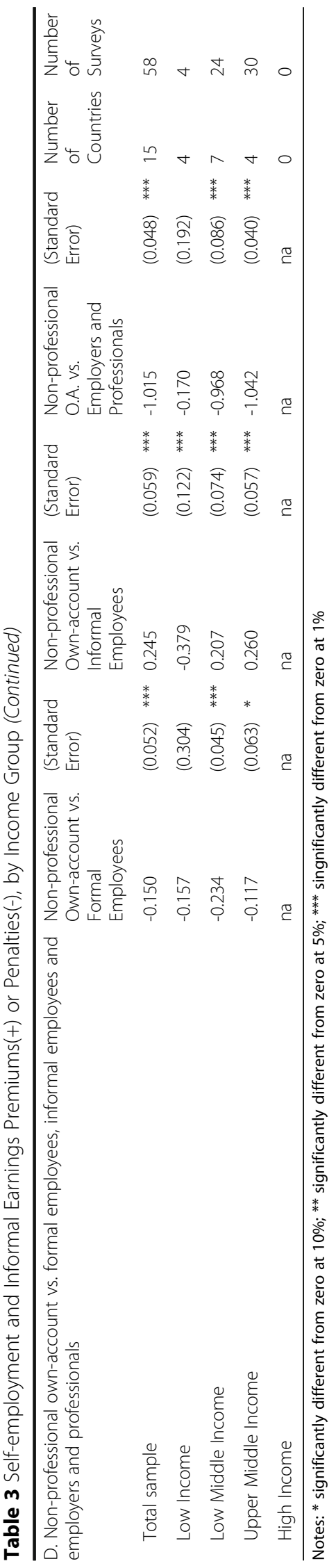


increases with GDP per capita, from less than 2 percent in low income countries to over 30 percent in lower-middle and upper-middle income countries (Table 3c).

Non-professional own-account workers in low income countries earn, on average, a premium relative to all employees, while non-professional own-account workers in high income countries pay a penalty (Table 3b). Broadly, the earnings of non-professional own-account workers relative to employees fall as the income per capita of a country increases. Figure $1 \mathrm{~b}$, which present the distribution of non-professional own-account

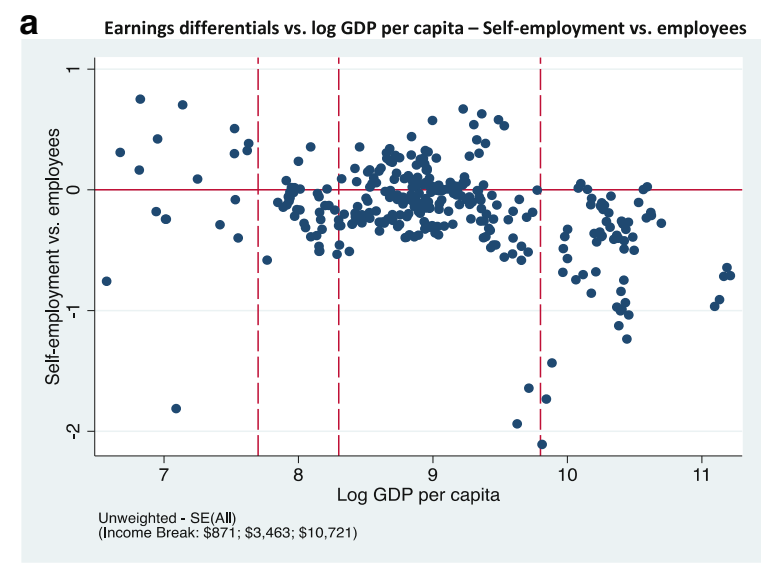

b Earnings differentials vs. log GDP per capita - Non-professional own-account vs. employees

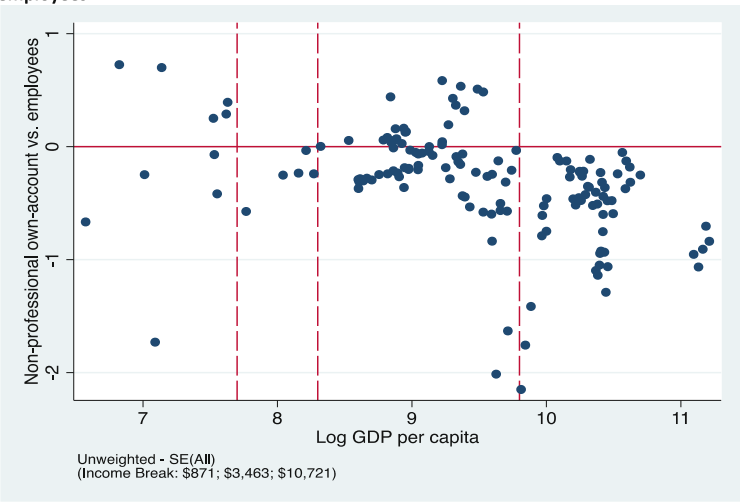

C Earnings differentials vs. log GDP per capita - Employers and professionals vs.

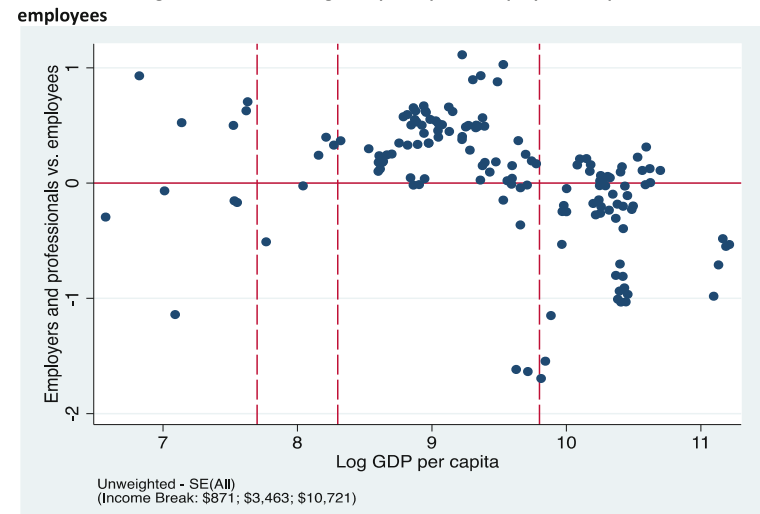

Fig. 1 a Earnings differentials vs. log GDP per capita - Self-employment vs. employees. b Earnings differentials vs. log GDP per capita - Non-professional own-account vs. employees. c Earnings differentials vs. log GDP per capita - Employers and professionals vs. employees 
earnings penalties and premiums by a country's income level, further illustrate this pattern. Many low income countries exhibit an earnings premium for non-professional own-account workers, for middle income countries the earnings differentials between non-professional own-account workers and employees cluster around zero (although most are negative (i.e. penalties)), while almost all high income countries exhibit earnings penalties. This pattern of increasing earnings penalties for self-employed workers persist whether we examine earnings differentials between the self-employed vs. employees (Fig. 1a) or non-professional own-account vs. employees (Fig. 1b). Moreover, the same pattern appears for all considered demographic sub-groups: urban, rural, male, female, by age group and education levels (Figs. 2, 3 and 4 and Tables 5, 6, 7, 8 and 9). Comparing non-professional own-account workers with formal employees is informative but comes at a major cost, as the sample is reduced from 42 to 15 countries. In that small sample, the estimated penalty faced by non-professional own-account workers relative to formal employees is similar across country income groups. Specifically, the estimated penalty is 16 percent (and statistically insignificant) in low income countries, and 23 and 12 percent in lower- and upper-middle income countries, respectively (See Table 3d).

Employers and professionals earn a statistically significant premium of over 50 percent in low and upper middle income countries (Table $3 \mathrm{~b}$ ). This premium falls to 8 percent and becomes statistically insignificant in high income countries. Figure 1c presents earnings differentials between employers and professionals vs. employees for the each country in our sample. Employers and professionals earn a premium in most low and middle income countries compared to employees. In many high income countries employers and professionals face a penalty compared to employees, and in countries where they earn a premium compared to employees the premium tends to be small.

\subsection{By Region of the World}

In Table 4 we report the results of the estimates of penalties (-) and premiums (+) by region of the world. As we have noted earlier, over 90 percent of our sample of surveys comes from either Latin America or Europe and Central Asia. Outside of Latin America and Europe and Central Asia, the largest group of surveys in our sample comes from Sub-Saharan Africa. We therefore focus on these regions in our regional analysis. We find some similarities between regions, but also some interesting differences, which suggest that care should be taken when generalizing the results from studies in Latin America to other regions of the world.

In all regions for which we have data (Latin America, developing Europe and East Asia, and Sub-Saharan Africa), non-professional own-account workers pay an earnings penalty relative to formal employees. Similarly, informal employees earn significantly less than formal employees in Latin America (but not in the developing middle income European and Central Asian economies). On the other hand, while employers and professionals earn statistically significant premiums compared to employees in Latin America and Sub-Saharan Africa, this is not true in Europe and Central Asia. In both high income and developing European and Central Asian economies there is no statistically significant difference in the earnings of employers and professionals compared to employees. Taken together, these results suggest that informal employees are 


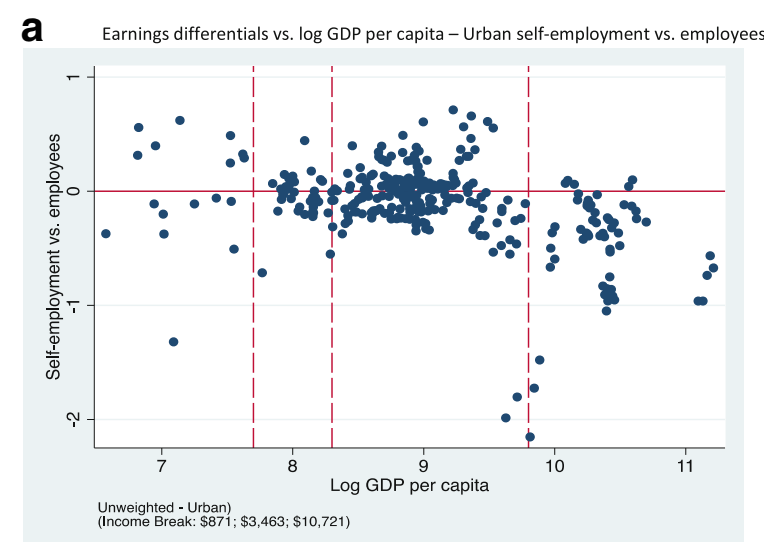

b Earnings differentials vs. log GDP per capita - Urban Non-professional ownaccount vs. employees

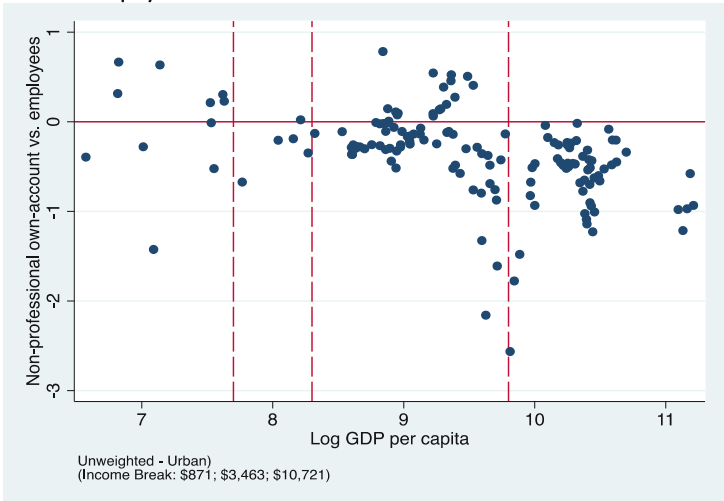

C Earnings differentials vs. log GDP per capita - Urban Employers and professionals vs. employees

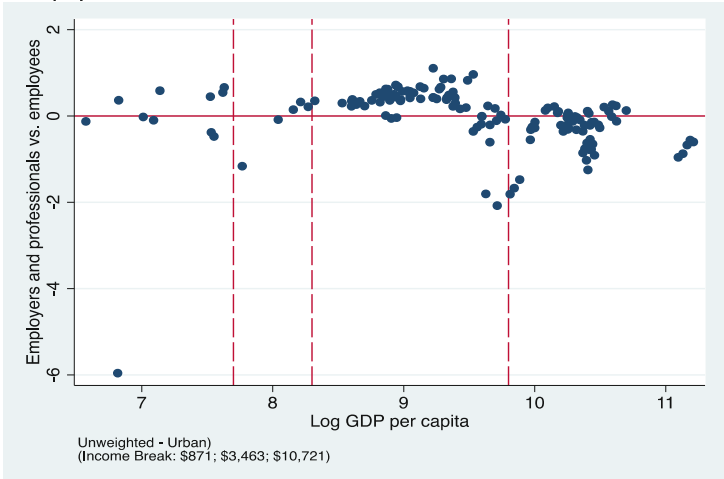

Fig. 2 a Earnings differentials vs. log GDP per capita - Urban self-employment vs. employees. b Earnings differentials vs. log GDP per capita - Urban Non-professional own-account vs. employees. c Earnings differentials vs. log GDP per capita - Urban Employers and professionals vs. employees

particularly disadvantaged in Latin America (but not in the developing economies of Europe and Central Asia), while employers and professional own-account workers do much better in Latin America and Sub-Saharan Africa than in Europe and Central Asia. As Latin American and the developing countries of Europe and Central Asia have similar GDP per capita, it is not likely that level of development explains these regional differences. 


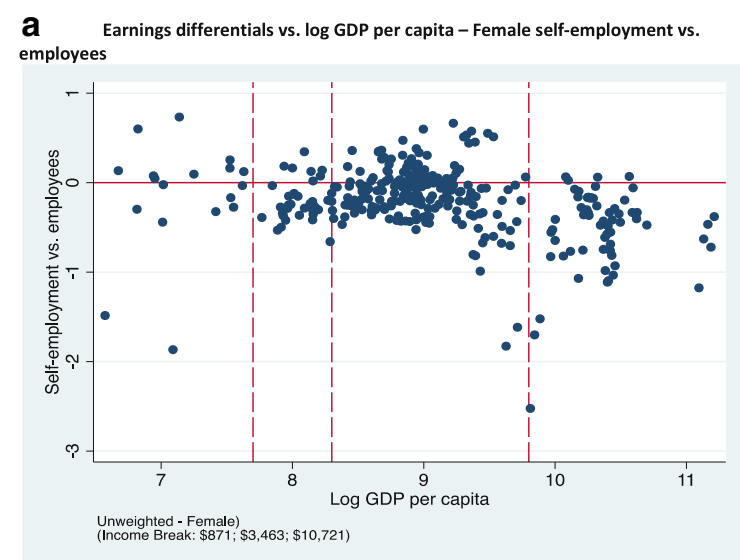

b Earnings differentials vs. log GDP per capita - Female Non-professional own-
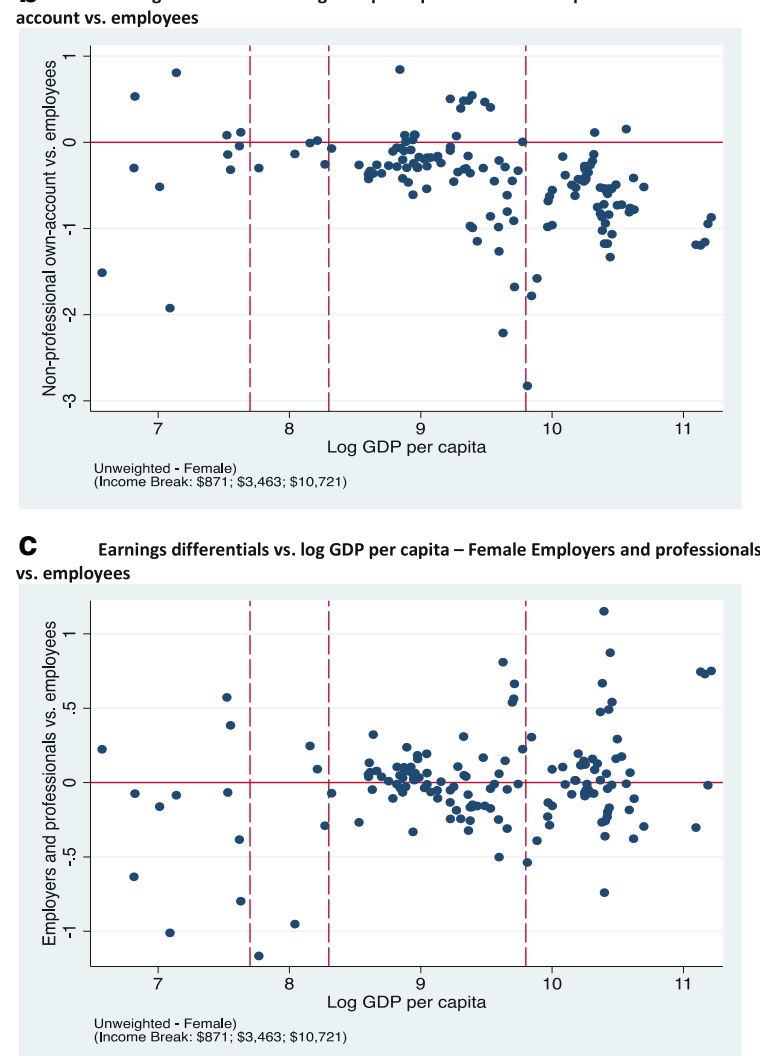

Fig. 3 a Earnings differentials vs. log GDP per capita - Female self-employment vs. employees. b Earnings differentials vs. log GDP per capita - Female Non-professional own-account vs. employees. c Earnings differentials vs. log GDP per capita - Female Employers and professionals vs. employees

\subsection{For Urban Workers Only}

Many analyses of self-employment and labor market segmentation focus on urban and non-agricultural labor markets. Therefore, it is useful to examine the results for only urban workers and see if they are consistent with results found using data for all workers (urban plus rural). ${ }^{8}$ Table 5 replicates Table 3 using data for only urban workers. 


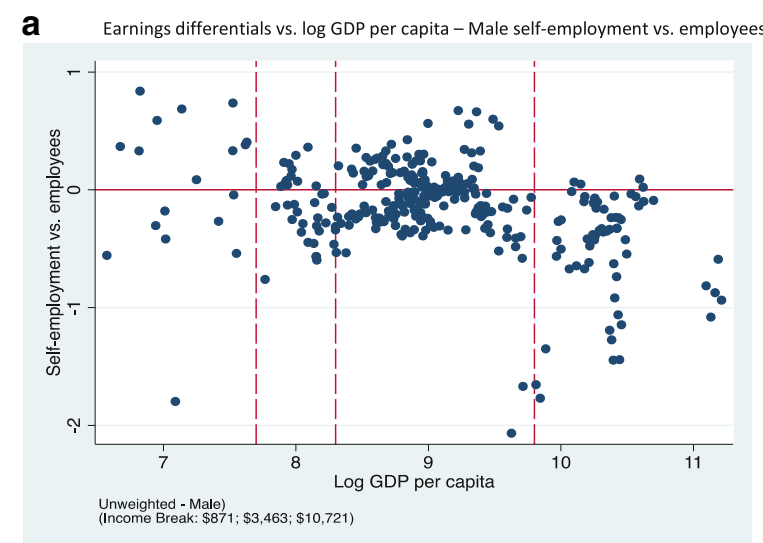

b Earnings differentials vs. log GDP per capita - Male Non-professional ownaccount vs. employees

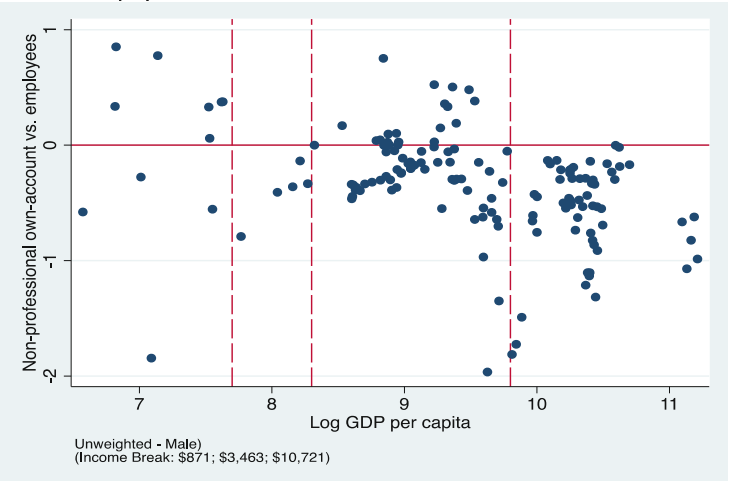

C

vs. employees

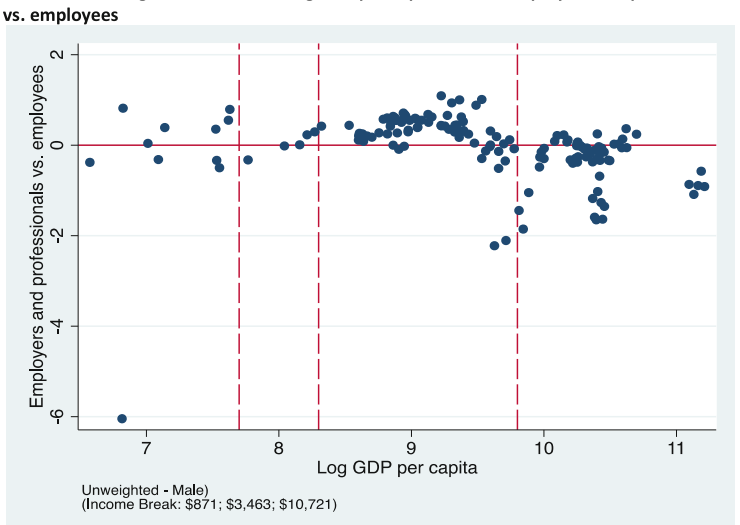

Fig. 4 a Earnings differentials vs. log GDP per capita - Male self-employment vs. employees. b Earnings differentials vs. log GDP per capita - Male Non-professional own-account vs. employees. c Earnings differentials vs. log GDP per capita - Male Employers and professionals vs. employees

There are no noticeable differences between Table 3 (urban plus rural) and Table 5 (urban only). The results for urban workers are similar to the results for all workers together. A clear ordering emerges across countries of all income levels. After controlling for education, age, gender, region of residence and industry sector, employers and professional own-account workers earn the most. Employers and professionals earn more than formal and informal employees, and more than non-professional own-account workers. After employers and professionals come formal sector employees, who earn 


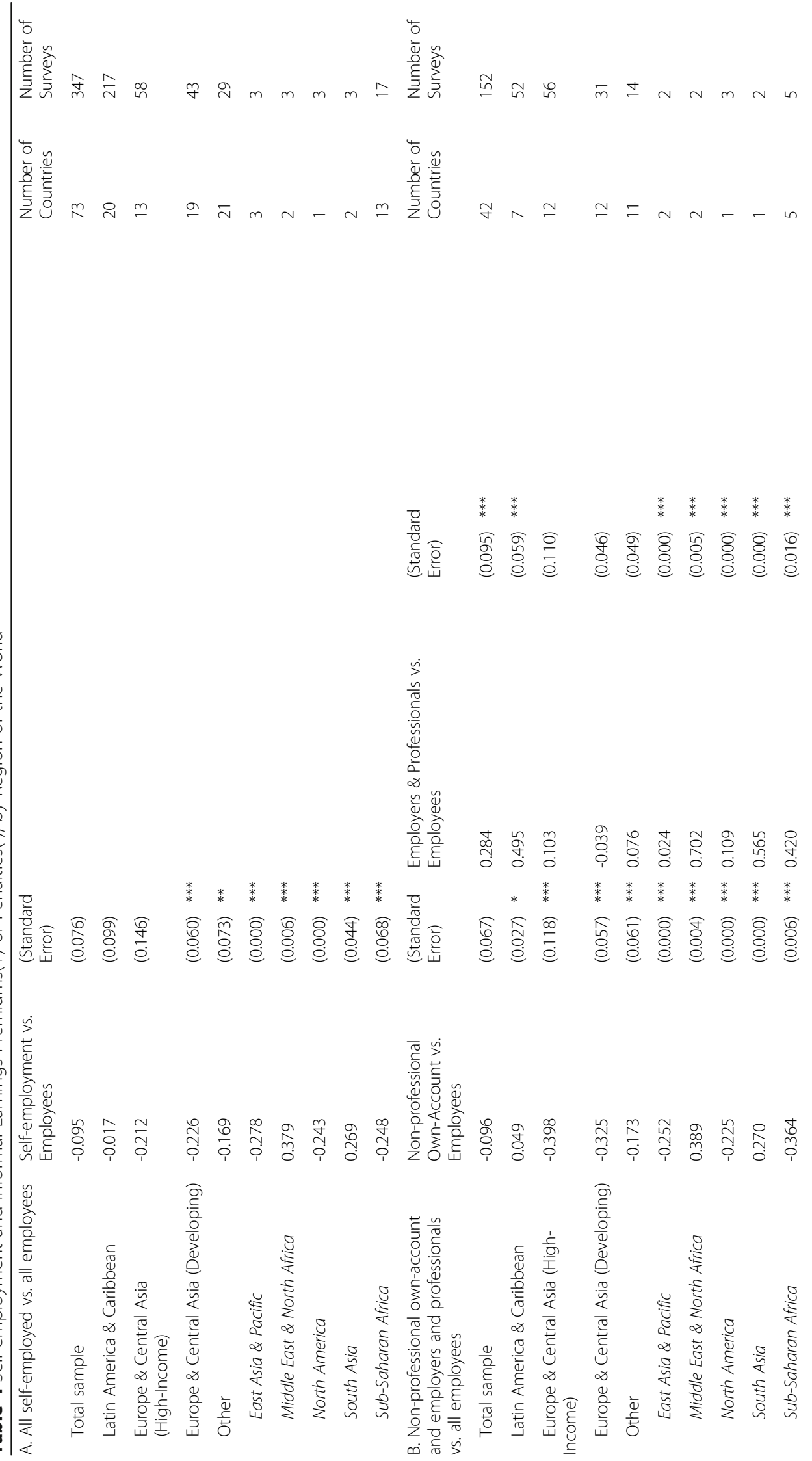




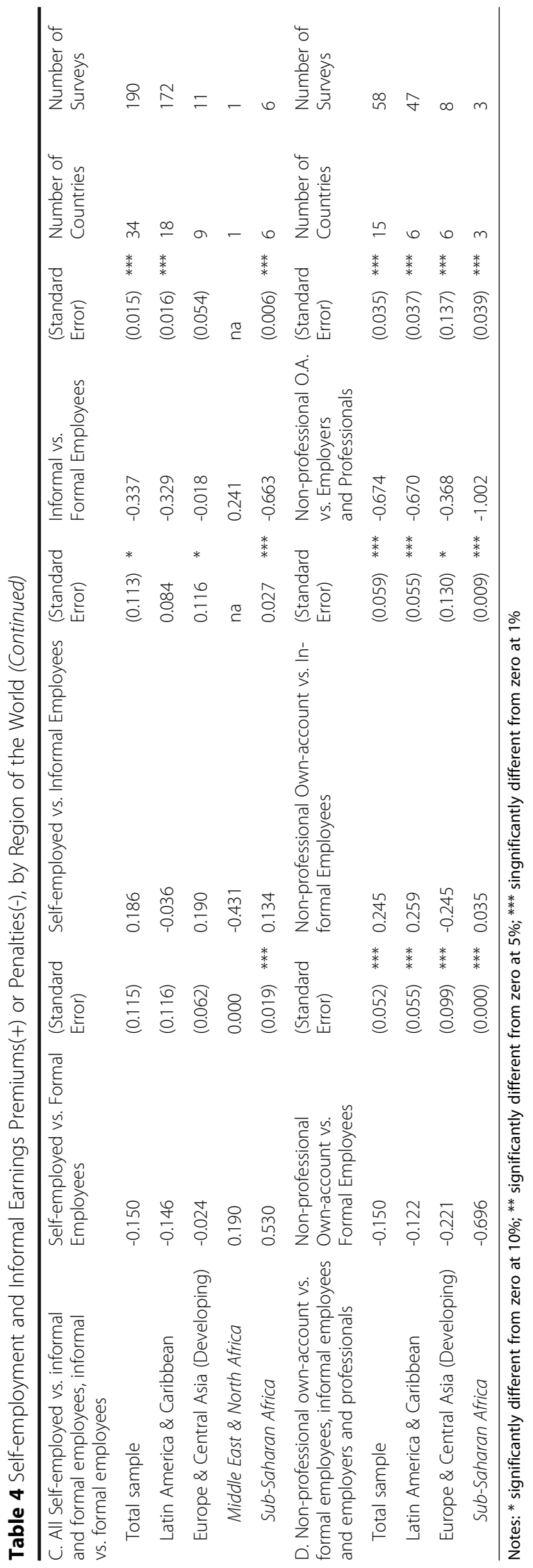




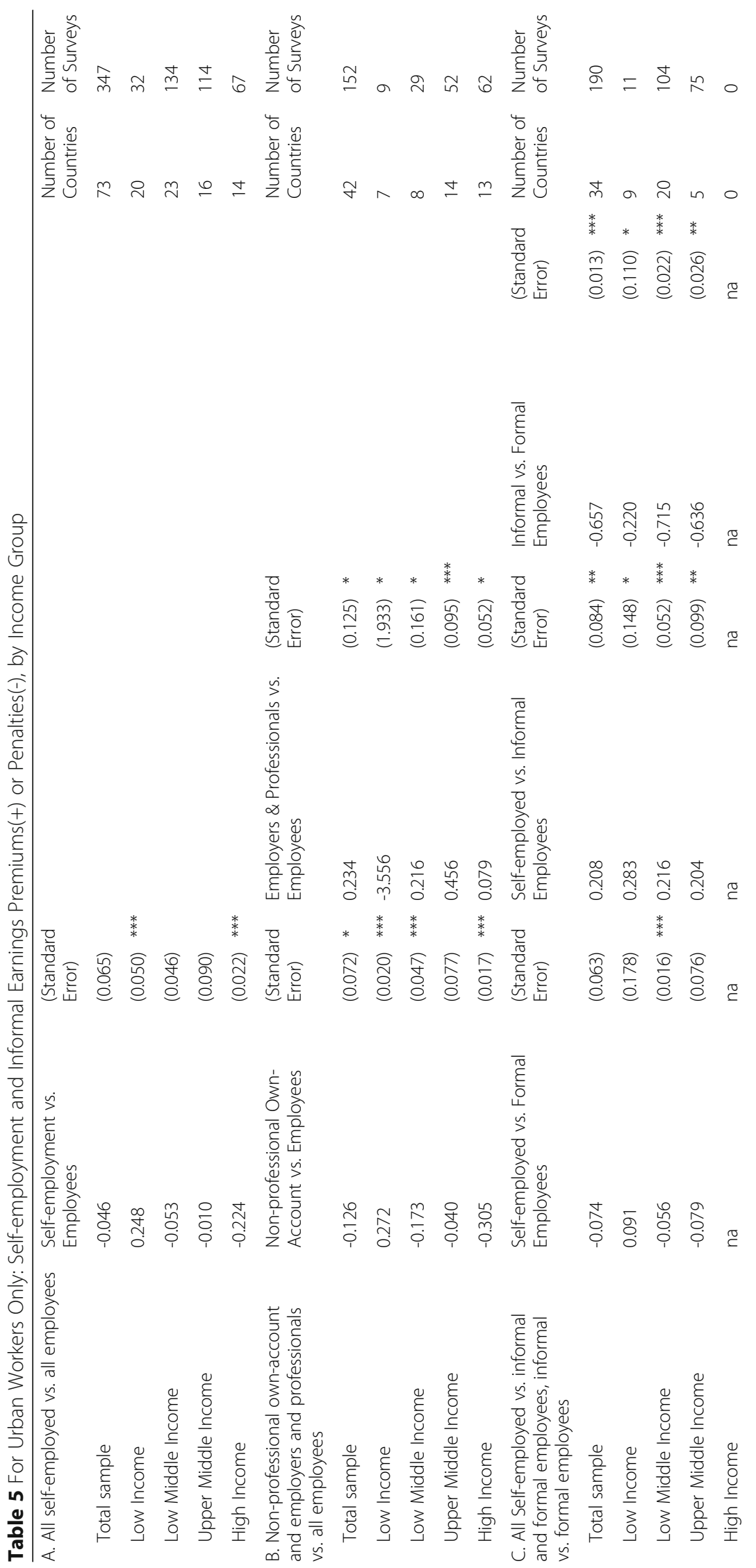




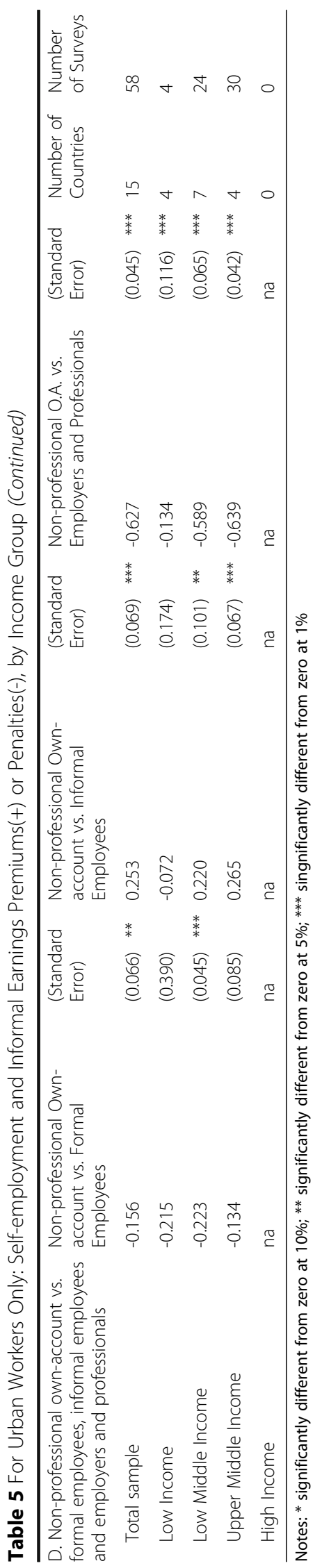


more than non-professional own-account workers and informal employees. Finally, non-professional own-account workers earn more than the lowest-paid category, informal employees.

In low income countries penalties for non-professional own-account workers vs. formal employees and for informal vs. formal employees are small. In middle income countries penalties for non-professional own-account workers vs. formal employees and for informal vs. formal employees are larger than in low income countries and are statistically different from zero. Penalties for non-professional own-account workers are largest and highly statistically significant in high income countries. Panels $a$ and $b$ in Fig. 2 further illustrate this pattern, presenting the distribution of self-employment earnings penalties and premiums by country income level. Most (but not all) low income countries exhibit a non-professional own-account earnings premium, middle income countries' earnings differentials cluster around zero (although most are penalties), and almost all high income countries exhibit penalties for non-professional own-account workers.

Figure 2c presents earnings differentials between employers and professionals vs. employees. In most low and middle income countries employers and professionals earn a premium compared to employees, while in most high income countries employers and professionals pay a penalty compared to employees.

\subsection{For Men and Women}

In most countries represented in the sample, women are primarily responsible for unpaid family responsibilities such as childcare, housework and elder care. This suggests that women may value the flexibility of self-employment more than men, and therefore may be willing to accept lower earnings to compensate for the greater flexibility in hours and location of work (a "motherhood wage gap"). It is possible that women's work tends to be undervalued and, in return, the wage structure within such countries might reflect that sentiment. It is possible, therefore, that self-employment and informal earnings penalties/premiums may differ between men and women. To examine this possibility, we re-estimate the entire set of earnings differentials separately for men and women. Tables 6 and 7 present the results.

The results show that both non-professional own-account men and women workers face earnings penalties compared to formal employees, but the penalties women face tend to be larger than those faced by men. The additional penalty faced by female nonprofessional own-account workers increases as the per-capita income of a country increases (Table 6). For example, the differences between men and women in the earnings penalty for non-professional own-account vs. formal employees are not significantly different from zero for low income countries, but are large and statistically significant in middle income countries. From middle income to high income countries, the gap between men and women increases further. Male-female differences in the earnings penalties between non-professional own-account workers compared to employees are largest in high income countries.

Differences between male and female employers and own-account professionals are even more striking. In middle and upper income countries, male employers and 


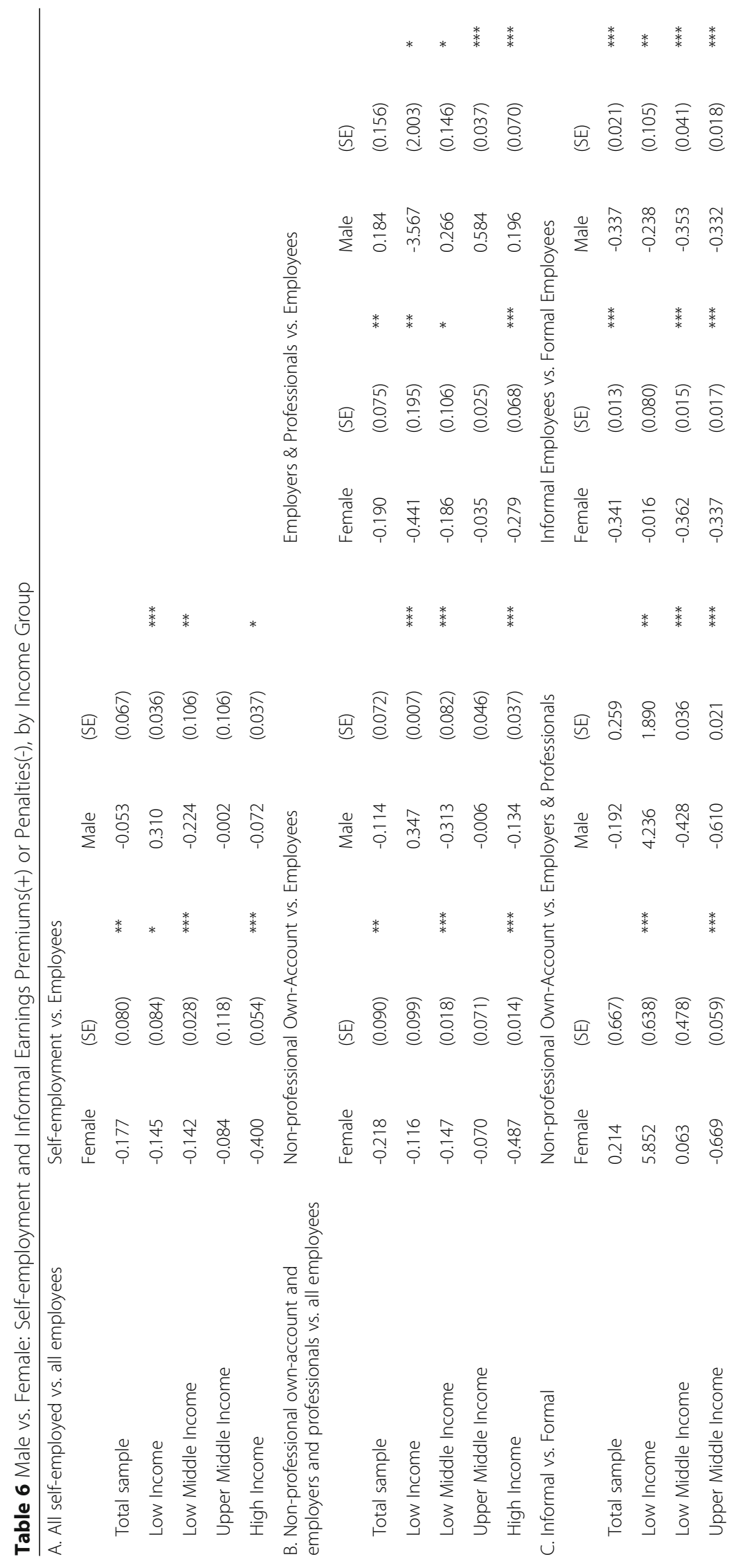




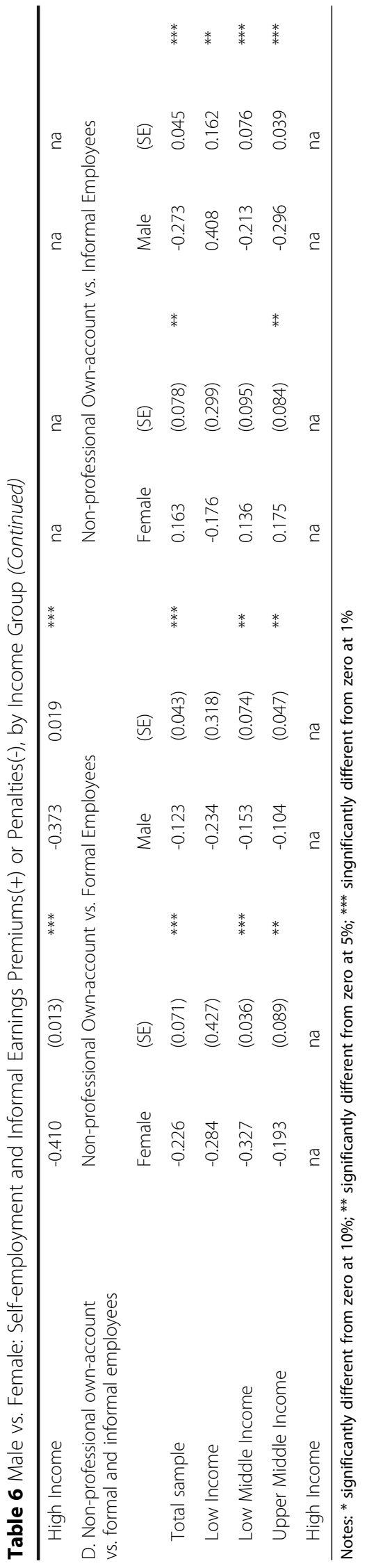




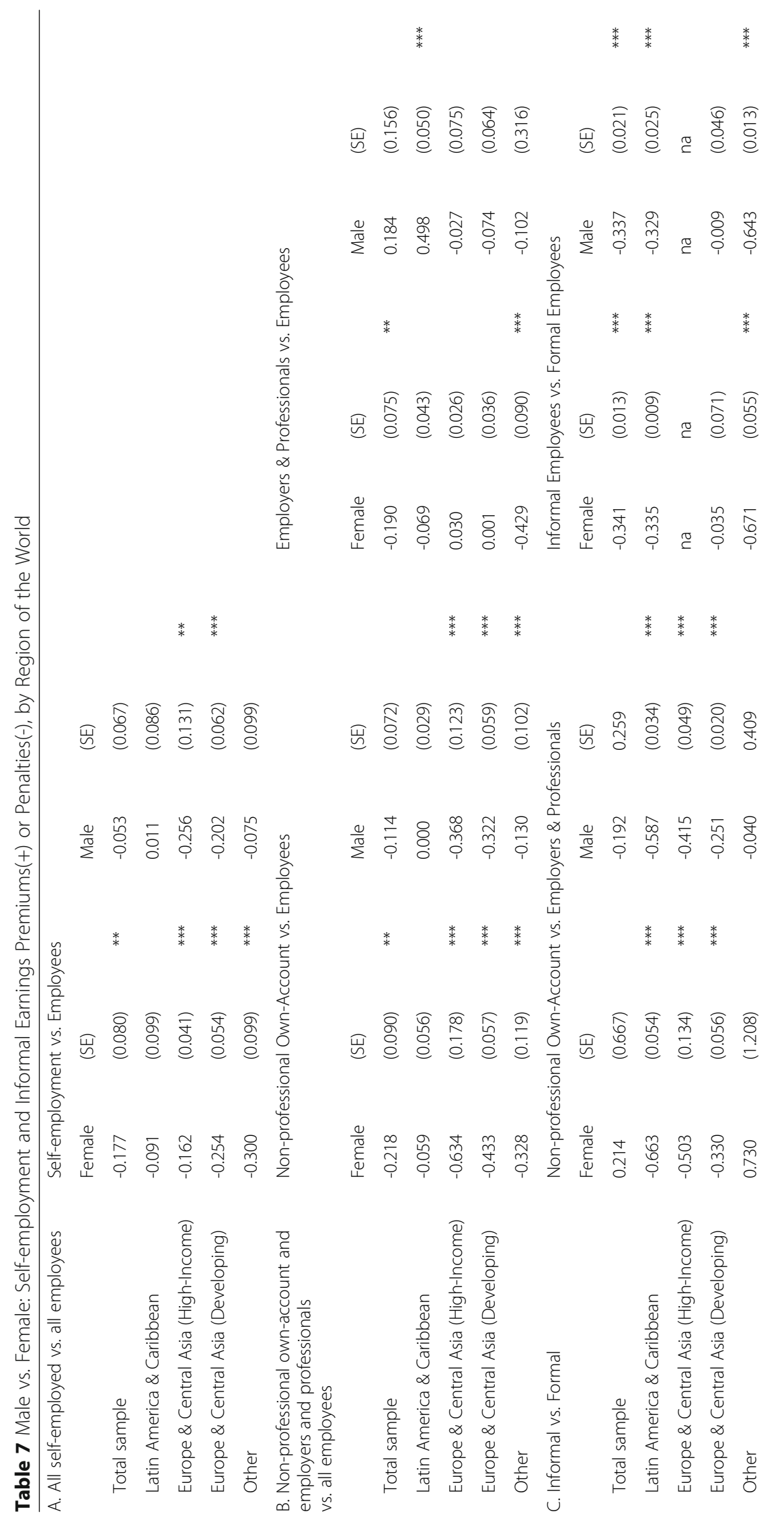




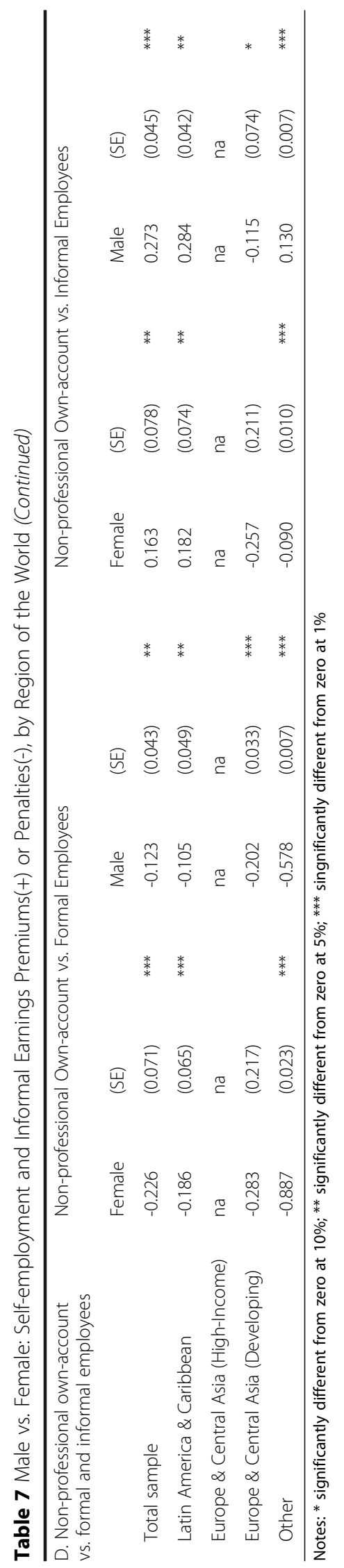


professionals earn a premium compared to employees, while women pay a penalty. These results suggest that women may be more willing than men to accept a negative compensating earnings differential for self-employment, and that this phenomenon is more pronounced in high income countries.

On the other hand, the earnings penalties paid for informal employment (vs. formal employment) are similar for men and women. This suggests that the differences between men and women in self-employment penalties/premiums may be because of compensating differentials for the flexibility of self-employment, while no similar flexibility exists for informal sector employees.

Table 7 presents earnings penalties/premiums, separately for men and women, for different regions of the world. In all regions women pay a higher penalty than men for non-professional own-account compared to formal employment. On the other hand, in all regions the earnings penalties for informal employment vs. formal employment are similar for men and women.

The most noticeable regional difference is in the earnings differences between employers and professionals vs. employees. In Latin America men earn a premium as employers and professionals but women do not, while in Europe and Central Asia neither men nor women earn a significant premium or penalty as employers and professionals.

Figures 3 and 4 present the distribution of earnings premiums/penalties for men and women by countries' GDP per capita. Patterns for each gender are similar to the overall patterns. Earnings penalties for both non-professional own-account workers and informal employees are small in low income countries and increase with GDP per capita.

\subsection{By Education Level}

Table 8 presents self-employment and informal/formal earnings penalties/premiums for workers at four education levels: primary incomplete, primary graduate, secondary graduate/university incomplete and university graduate. ${ }^{9}$ In general, there are statistically significant self-employment earnings premiums for less educated workers in low income countries, but statistically significant earnings penalties for this group in middle and high income countries. Self-employment earnings premiums/penalties are not significantly different from zero for the most part for self-employed secondary and university graduates.

At all education levels, informal employees face earnings penalties compared to formal employees. Also at all levels of education, earnings penalties faced by informal employees increase as a countries' GDP per capita increases. Across all education levels, informal earnings penalties are small and often insignificant in low income countries and increase and become statistically significant in middle income countries.

\subsection{By Age}

Previous research suggests that successful self-employed workers tend to be older, midcareer workers. This suggests that we might find earnings premiums for the older selfemployed but earnings penalties for the younger self-employed. To examine this issue, Table 9 presents earnings differentials for self-employed vs. employees, nonprofessional own-account vs. employees and employers and professionals vs. employees for three age groups: 15-24, 25-44 and 45-64. Neither earnings penalties for non- 


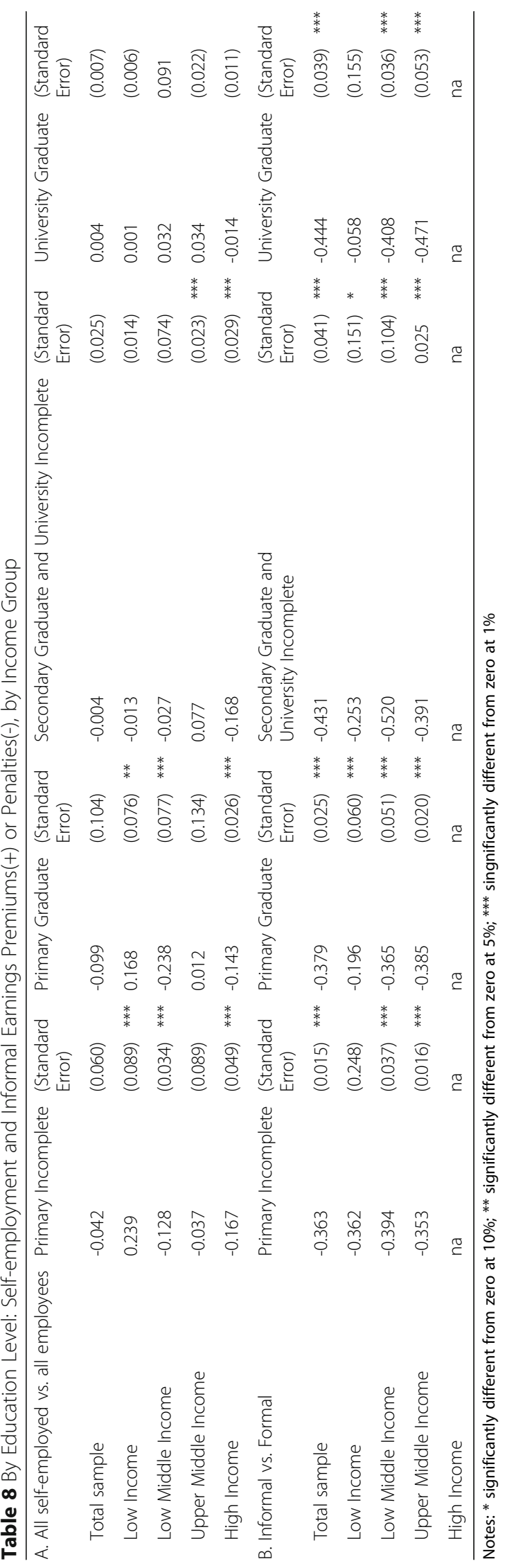




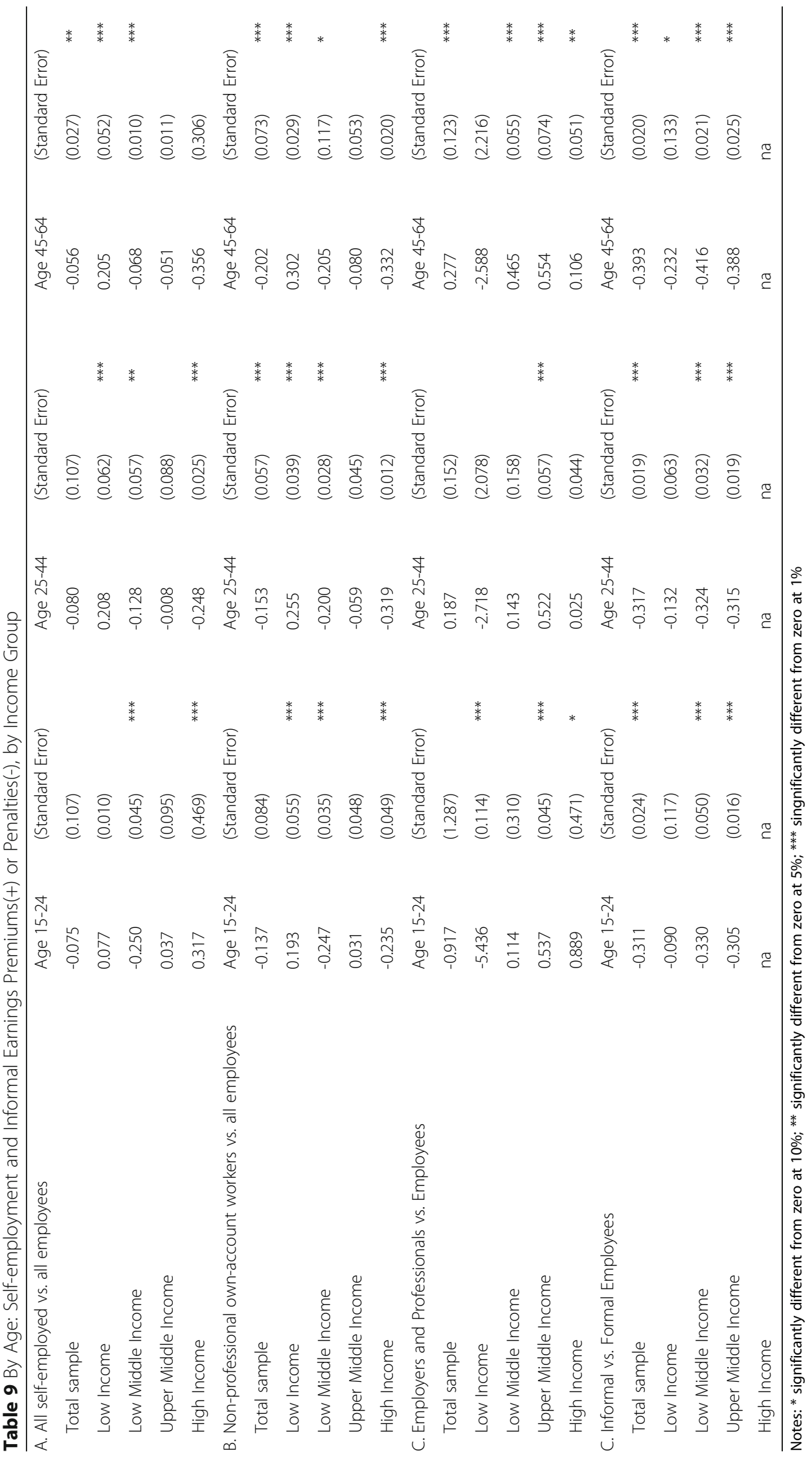


professional own-account workers nor earnings premiums for employers and professionals show any clear pattern between age groups; for some income groups they are bigger for older workers and for other income groups they are smaller for older workers compared to younger workers.

For all age levels, informal employees face earnings penalties compared to formal employees. Also at all age levels, earnings penalties faced by informal employees increase as a countries' GDP per capita increases. Informal earnings penalties are small and often insignificant in low income countries and increase and become statistically significant in middle income countries.

\subsection{Discussion and Interpretation of Results}

Whether self-employed workers pay a penalty or earn a premium depends on a variety of factors, including their country's level of development, where it is located, the worker's gender, and whether those self-employed workers are employers (entrepreneurs) and skilled own-account professionals or are (presumably unskilled) nonprofessional own-account workers. On this last point, employers and own-account professionals tend to earn greater premiums, which is consistent with the hypothesis that their earnings reflect not only their greater productivity, but also returns to capital and risk. In other words, employers and professionals are likely to receive positive earnings compensating differential to make up for the additional costs or risks involved in starting their own business.

Male employers and professional own-account workers in many developing countries enjoy a particularly large earnings premium compared to formal employees, while female employers and professionals do not. In fact, our estimates suggest that female employers and professionals in low and high income countries pay a statistically significant penalty compared to employees, while in middle income countries estimated penalties are statistically insignificant. These gender differences are consistent with the hypothesis that women are more willing to accept lower wages as compensating earnings differentials for the flexibility of self-employment.

The premiums earned by employers and own-account professionals also vary by region. These workers earn large and statistically significant premiums compared to employees in Latin America. But in high income and developing economies in Europe and Central Asia, there is no significant difference in the earnings of employers and professionals compared to formal employees. This suggests either that employers and professionals face disadvantages in Europe and Central Asia that they do not face in Latin America or Sub-Saharan Africa, or that Latin American employers require greater profits to enter or maintain their business than those in Europe.

Evidence on labor market segmentation is mixed, and much stronger for middle income countries than for low income countries. In developing countries, nonprofessional self-employed workers face earnings penalties compared to formal employees. This result is consistent with the hypothesis of labor market segmentation in developing countries. However, we also find evidence that as the per capita GDP of a country increases the earnings of the self-employed fall relative to the earnings of formal employees. This is true for both non-professional own-account workers and employers and professional own-account workers. This finding is not consistent with the 
hypothesis that labor market segmentation is causing penalties for self-employment. Instead, it is more consistent with the hypothesis that earnings differentials are due to compensating differentials where self-employed workers are willing to pay an earnings penalty in exchange for the flexibility of self-employment.

Evidence on segmentation for informal wage employees follows a similar pattern. Informal employees in developing countries tend to face earnings penalties relative to formal employees, which is consistent with labor market segmentation between the formal and informal employment in developing countries caused by the exclusion of informal employees from the formal sector. However, earnings penalties faced by informal employees are low and insignificant in low income countries and large and statistically significant in middle income countries. This suggests that labor market segmentation between formal and informal employment is more prominent in middle income countries than in low income countries.

Examined differently, the increase in the self-employment and informal earnings penalty as GDP increases indicates that as countries develop formal employees' earnings increase faster than those of the self-employed or informal sector employees. This suggests that the focus should be on what happens to formal employees rather than selfemployed and informal employees. This is true in one traditional dualistic model of economic development where the formal sector in the least developed countries is small (and self-employment and informal employment are large) because of lack of demand for formal sector products is insufficient to allow for the necessary economies of scale (see Lewis 1954 and La Porta and Schleifer 2014). For this reason, formal sector firms in low income countries will be less productive. As demand increases for domestic products, the scale of production and productivity increase in the formal sector. This will lead to an increase in the proportion of workers in formal employment as well as an increase in earnings for formal sector employees, which in turn will lead to larger penalties for informal employees and non-professional self-employed.

Our evidence is thus consistent with the view that earnings gaps between the selfemployed, informal employees and formal employees are due to efficiency wages and the sharing of quasi-rents in formal sector firms. Because it is likely that formal sector firms in low income countries are less productive than those in more developed countries, and offer fewer resources that boost worker productivity, these firms earn fewer rents that can be shared with workers. As countries develop and firms gain access to innovative technologies, the productivity of employees in firms increases, allowing firms to share more of their quasi-rents with workers. This increases the wages of formal employees relative to the self-employed and informal employees. It is also reasonable to expect that the bargaining power of formal employees will also increase as countries develop, due to the increasing prevalence of unions and the better enforcement of labor regulations. If the bargaining power of workers is positively correlated with level of development and labor productivity, then the correlation between the employee's share of quasi-rents and development and productivity will be even stronger.

\section{Conclusion}

We find that approximately half of all workers in low income countries are nonprofessional own-account workers, while only 9 percent are formal employees, and only 2 percent of workers in low income countries are employers or professionals. As 
countries develop, the proportion of workers who are formal employees, employers and professional own-account workers increases, while the proportion of workers who are non-professional own-account workers falls. In high income countries, nonprofessional own-account workers make up 7 percent of all workers, employers and professionals make up less than 5 percent are, and almost 90 percent are employees.

The proportion of self-employed is smallest in the developing economies of Europe and Central Asia. Our most comprehensive estimate is that approximately 95 percent of workers in the developing economies of Europe and Central Asia are wage and salaried employees. This is higher than the 68 percent of Latin American and the Caribbean workers who are employees and even higher than the proportion of workers who are employees in high income European countries.

Across all regions and income levels, non-professional own-account workers and informal employees face an earnings penalty compared to formal employees. This penalty is statistically significant in all regions except for the developing economies of Europe and Central Asia, where the penalty is small and often not statistically significant. In addition, both the non-professional own-account and informal earnings penalties are small (and often not statistically significant) in low income countries, The penalties to being non-professional self-employed or informal increase as a country's GDP increases. The earnings penalties for informal employees are largest in middle income countries, and the earnings penalties for non-professional own-account workers are largest in high income countries.

Across all countries, on average, we find that employers and own-account professionals enjoy an earnings premium compared to employees, with major differences between men and women. While earnings premiums for employers and professionals are largest for men in middle income and Latin American countries, their female counterparts consistently earn a penalty in all countries (or an insignificant premium). Further, we find that neither male nor female employers and professionals earn premiums in Europe and Central Asia. This we believe might be due to fundamental differences in labor market and other regulations and laws, which can directly affect earnings premiums/penalties, between Latin America where employers and professionals are favored and Europe and Central Asia where employers and professionals are penalized.

Gender differences are particularly striking for employers and professionals. Statistically significant measured earnings premiums for male employers and professionals are consistent with the hypothesis that men in these categories have a comparative advantage in self-employment, or are being compensated for the higher costs and risks of self-employment compared to wage and salaried employees. The sizeable average penalties for female employers and professionals suggests that men and women make different calculations when deciding to become and remain employers or professional workers. One possibility is that because women are primarily responsible for unpaid domestic work, women are more willing to accept lower earnings as employers and professional own-account workers as compensation for flexibility in hours and location of work.

In general, the findings are not consistent with high rates of labor market segmentation in low income countries as an explanation for the high levels of self-employment. In these countries, we find small earnings penalties for own-account non-professional workers relative to formal employees, and in a larger sample of countries own-account 
non-professional workers earn an earnings premium relative to all wage employees. As countries develop, these premiums decline and become substantial penalties in high income countries. This evidence runs counter to the standard labor market segmentation view, in which self-employment is prevalent in the poorest economies because most workers are excluded from the formal economy, and the formal economy is incapable of providing sufficient high-wage jobs for everyone who wants them. According to this standard view, the proportion of workers who are self-employed falls as countries develop and the wage differential between the self-employed and employees should eventually disappear.

Instead, evidence of moderate amounts of segmentation appears to be stronger in middle and high income countries than low income countries. In particular, as GDP per capita of a country increases, the earnings of formal employees increase relative to employers and professionals, non-professional own-account workers and informal employees. We highlight two other hypotheses that are consistent with the trend that earnings of formal employees increase relative to that of self-employed and informal employees as GDP per capita increases. One is a dualistic economy model where formal sector firms in low income countries have low productivity because a lack of credit, lack of reliable inputs, lack of export markets and lack of demand do not allow them to take advantage of economies of scale. For these reasons, formal sector firms in low income countries will be less productive and employee wages will be low. As countries develop, demand increases, and credit and export markets develop, thus the productivity of formal sector firms increases. The increase in productivity allows firms to share rents with workers, driving up the earnings of formal employees relative to informal employees and self-employed workers.

The second hypothesis is that self-employed workers may be willing to accept lower earnings as compensation for increased flexibility in terms of hours and location of work. This is likely to especially be true for women who are responsible for the majority of unpaid domestic work such as childcare or elder care. Self-employment may be valued because it provides the flexibility that allows for both domestic work and paid employment, whereas wage and salaried employment with inflexible working hours does not. The compensating differential explanation suggests that the self-employment earnings penalty will be particularly large in more developed countries, where the opportunity cost of time is higher and therefore the flexibility of self-employment will be valued more. Evidence supporting this last hypothesis is that penalties for self-employment are larger for women than for men, and that the additional penalty that women pay for selfemployment, compared to men increases as GDP per capita increases.

\section{Endnotes}

${ }^{1}$ The costs of searching for wage employment include information costs. A lack of information may help to create a self-employment wage penalty. For example, selfemployed farmers in rural areas in developing countries may not be aware that they could earn more in urban areas (Brya et al. 2012; Jensen 2012).

${ }^{2}$ See, among others, Dickens and Katz (1987) and Krueger and Summers (1988).

${ }^{3}$ The database is an updated version of that described in Montenegro and Hirn (2009). Version 4 of the I2D2, which was released in October 2013, was used for this study. 
${ }^{4}$ Self-employed workers include those who self-identify as either an own-account worker or an owner/employer. We use the ILO definition of own-account workers as "workers who, working on their own-account or with one or more partners, hold the type of job defined as a self- employed job, and have not engaged on a continuous basis any employees to work for them during the reference period" (http://aborsta.ilo.org/ applv8/data/icsee.html).

${ }^{5}$ The frequency of wage payments is included as a control in order to guard against errors in the coding of wage payment frequencies across surveys, which could otherwise severely distort the results.

${ }^{6}$ These results are consistent with the findings of our earlier work in Gindling and Newhouse (2014).

${ }^{7}$ It should be noted that our MENA sample is limited to only Yemen and Djibouti while our South Asia sample is represented by Bangladesh and Pakistan which might not be representative of the entire regions.

${ }^{8}$ Results for non-agricultural workers only are similar to those presented for urban workers only.

${ }^{9}$ Because professional own-account workers are almost surely university graduates, it does not make sense to report earnings differentials by education level separately for employers and professionals and non-professional own-account workers.

\section{Additional file}

Additional file 1: Table S1. Earnings Differentials for various workers by country, year and region of the world. (DOCX $1449 \mathrm{~kb})$

\section{Acknowledgements}

We would like to thank Claudio E. Montenegro and his team of research assistants for their efforts to create and maintain the data and for helping with data-related questions. We are also grateful for helpful comments from Lisa Dickson, Marvin Mandell, David Marcotte and Hartmut Lehmann. We are also grateful for comments and suggestions from seminar participants at the World Bank's Labor and Poverty Practice Group, George Mason University, and UMBC, as well as the 2014 IZA/World Bank Conference on Employment and Development in Lima, the October 2016 Workshop on Job Quality in Post-transition, Emerging and Developing Countries in Rome and the November 2016 Jobs and Development Conference in Washington.

Competing interests

The IZA Journal of Labor \& Development is committed to the IZA Guiding Principles of Research Integrity. The authors declare that they have observed these principles.

\section{Author details}

${ }^{1}$ UMBC, Baltimore, MD, USA. ${ }^{2}$ Poverty and Equity Global Practice, World Bank, Washington, DC, USA.

Received: 22 October 2016 Accepted: 3 November 2016

Published online: 28 December 2016

\section{References}

Abowd J, Kramarz F, Lengermann P, McKinney K, Roux S (2012) Persistent Inter-industry Wage Differences: Rent Sharing and Opportunity Costs. IZA J Labor Econ 1(7). doi:10.1186/2193-8997-1-7

Arias O, Khamis M (2009) Comparative Advantage, Segmentation and Informal Earnings: A Marginal Treatment Effects Approach. IZA Discussion Paper No. 3916

Asteibro T, Chen J (2014) The Entrepreneurial Puzzle: Mismeasurement or Real? J Bus Ventur 28:88-105

Bargain O, Kwenda P (2011) Earnings Structures, Informal Employment, and Self-Employment: New Evidence From Brazil, Mexico, and South Africa. Rev Income Wealth 57(S1):S100-S122

Basch M, Paredes-Molina RD (1996) Are There Dual Labor Markets in Chile?: Empirical Evidence. J Dev Econ 50(2):297312

Bennett J, Estrin S (2010) Informal Firms in Developing Countries: Entrepreneurial Stepping Stone or Consolation Prize? Small Bus Econ 34(1):53-63

Brya G, Chowdhury SK, Mobarak AM (2012) Seasonal Migration and Risk Aversion. Centre for Economic Policy Research Discussion Paper No. DP8739 
Cahuc P, Postel-Vinay F, Robin J (2006) Wage bargaining with on-the-job search: Theory and Evidence. Econometrica 74(2):323-364

De Mel S, McKenzie D, Woodruff C (2010) Who Are the Microenterprise Owners? Evidence from Sri Lanka on Tokman versus De Soto. In: Lerner J, Schoar A (eds) International Differences in Entrepreneurship. University of Chicago Press, Chicago, pp 63-87

De Soto H (1989) The Other Path: The Economic Answer to Terrorism. HarperCollins, New York

Dickens W, Katz LF (1987) Inter-Industry Wage Differences and Industry Characteristics. In: Lang K, Leonard J (eds) Unemployment and the Structure of Labor Markets. Blackwell, New York, pp 48-89

Fields GS (2005) A Guide to Multisector Labor Market Models. World Bank, Social Protection Working Paper No. 0505

Fields GS (2009) Segmented Labor Market Models in Developing Countries. In: Ross D, Kincaid H (eds) The Oxford Handbook of Philosophy of Economics. Oxford University Press, New York, pp 476-510

Gasparini L, Tornarolli L (2007) Labor Informality in Latin America and the Caribbean: Patterns and Trends from Household Survey Data. Centro de Estudios Distributivos, Laborales y Sociales (CEDLAS) Working Paper No. 46

Gindling TH (1991) Labor Market Segmentation and the Determination of Wages in the Public, Private-Formal, and Informal Sectors in San Jose, Costa Rica. Econ Dev Cult Chang 39(3):585-60

Gindling TH, Newhouse D (2014) "Self-Employment in the Developing World". World Dev 56:313-331

Günther I, Launov A (2012) Informal Employment in Developing Countries: Opportunity or Last Resort? J Dev Econ 97(1):88-98

Harris JR, Todaro MP (1970) Migration, Unemployment and Development: A Two-Sector Analysis. Am Econ Rev 60(1): $126-142$

Heckman JJ, Hotz VJ (1986) An Investigation of the Labor Market Earnings of Panamanian Males: Evaluating the Sources of Inequality. J Hum Resour 21(4):507-542

Hurst E, Li G, Pugsley B (2010) Are Household Surveys Like Tax Forms: Evidence from Income Underreporting of the Self Employed. NBER Working Paper 16527

Jensen R (2012) Do Labor Market Opportunities Affect Young Women's Work and Family Decisions? Experimental Evidence from India. Q J Econ 127(2):753-792

Krueger AB, Summers LH (1988) Efficiency Wages and the Inter-industry Wage Structure. Econometrica 56(2):259-93

La Porta R, Schleifer A (2014) Informality and Development. J Econ Perspect 28(3):109-126

Launov A (2006) Competitive and Segmented Informal Labor Markets. IZA Discussion Paper No. 2349

Lehmann H (2015) Informal Employment in Transition Countries: Empirical Evidence and Research Challenges. Comp Econ Stud 57(1):1-30

Lewis A (1954) Economic Development with Unlimited Supplies of Labor. Manch Sch Econ Soc Stud 22(2):139-91

Maloney WF (1999) Does Informality Imply Segmentation in Urban Labor Markets? Evidence from Sectoral Transitions in Mexico. World Bank Econ Rev 13(2):275-302

Meghir C, Narita R, Robin JM (2015) Wages and informality in developing countries. Am Econ Rev 105(4):1509-1546

Mincer J (1962) On-the-Job Training: Costs, Returns, and Some Implications. J Polit Econ 70(5):50-79

Montenegro CE, Hirn M (2009) A New Disaggregated Set of Labor Market Indicators Using Standardized Household Surveys from Around the World. Background Paper for the World Development Report 2009

Nguyen HC, Nordman C, Roubaud F (2013) Who Suffers the Penalty? A Panel Data Analysis of Earnings Gaps in Vietnam. IZA Discussion Paper 7149

Perry G, Maloney W, Arias O, Fajnzylber P, Mason A, Saavedra J (2007) Informality: Exit and Exclusion. World Bank (Latin America and Caribbean Studies), Washington

Saavedra J, Chong A (1999) Structural Reform, Institutions and Earnings: Evidence from the Formal and Informal Sectors in Urban Peru. J Dev Stud 35(4):95-116

Sorgner A, Fritsch M, Kritikos A (2014) Do Entrepreneurs Really Earn Less? IZA Discussion Paper No. 8651

Tokman VE (1978) An Exploration into the Nature of Informal-formal Sector Relationships. World Dev 9:1065-1075

Van Reenen J (1996) The Creation and Capture of Rents: Wages and Innovation in a Panel of U.K. Companies. Q J Econ 111(1):195-226

\section{Submit your manuscript to a SpringerOpen ${ }^{\circ}$ journal and benefit from:}

- Convenient online submission

Rigorous peer review

- Immediate publication on acceptance

- Open access: articles freely available online

- High visibility within the field

Retaining the copyright to your article

Submit your next manuscript at $\boldsymbol{\nabla}$ springeropen.com 